\title{
Endometrial stem/progenitor cells and their roles in immunity, clinical application, and endometriosis
}

Yue Kong ${ }^{1,2}$, Yang Shao ${ }^{1,2}$, Chunxia Ren ${ }^{3^{*}}$ and Gong Yang ${ }^{1,2,4^{*}}$ (])

\begin{abstract}
Endometrial stem/progenitor cells have been proved to exist in periodically regenerated female endometrium and can be divided into three categories: endometrial epithelial stem/progenitor cells, CD140b ${ }^{+}$CD $146^{+}$or SUSD2 ${ }^{+}$endometrial mesenchymal stem cells (eMSCs), and side population cells (SPs). Endometrial stem/progenitor cells in the menstruation blood are defined as menstrual stem cells (MenSCs). Due to their abundant sources, excellent proliferation, and autotransplantation capabilities, MenSCs are ideal candidates for cell-based therapy in regenerative medicine, inflammation, and immune-related diseases. Endometrial stem/progenitor cells also participate in the occurrence and development of endometriosis by entering the pelvic cavity from retrograde menstruation and becoming overreactive under certain conditions to form new glands and stroma through clonal expansion. Additionally, the limited bone marrow mesenchymal stem cells (BMDSCs) in blood circulation can be recruited and infiltrated into the lesion sites, leading to the establishment of deep invasive endometriosis. On the other hand, cell derived from endometriosis may also enter the blood circulation to form circulating endometrial cells (CECs) with stem cell-like properties, and to migrate and implant into distant tissues. In this manuscript, by reviewing the available literature, we outlined the characteristics of endometrial stem/progenitor cells and summarized their roles in immunoregulation, regenerative medicine, and endometriosis, through which to provide some novel therapeutic strategies for reproductive and cancerous diseases.
\end{abstract}

Keywords: Stem cells, Endometriosis, Human endometrium, Immunology

\section{Introduction}

Endometrium can be divided into shallow and deep layers based on the structure. The shallow layer is called functional layer that experiences periodic changes of proliferation, secretion, and shedding under the regulation of hormones. The deep layer is named as basal layer.

\footnotetext{
*Correspondence: renchunxia2018@shutcm.edu.cn; yanggong@fudan.edu. $\mathrm{cn}$

${ }^{1}$ Cancer Institute, Fudan University Shanghai Cancer Center,

Shanghai 200032, China

${ }^{3}$ Center for Reproductive Medicine, Shuguang Hospital Affiliated

to Shanghai University of Traditional Chinese Medicine, Shanghai 200120, China

Full list of author information is available at the end of the article
}

The basal layer owns strong proliferation and repair abilities without falling off during the menstrual period but generates new functional layers. The periodic endometrial regeneration implies the presence of stem/ progenitor cells in the endometrium. Gargett et al. first revealed the existence of adult stem/progenitor cells in endometrium by identification of rare clonogenic cells or colony-forming units (CFUs) from purified single-cell suspensions of hysterectomy tissues in 2004 [1]. Since then, the study of endometrial stem/progenitor cells has been highly developed. At present, based on cell types and identification techniques, endometrial stem/progenitor cell population is defined as $\mathrm{CD}_{140 \mathrm{~b}^{+} \mathrm{CD} 146^{+}}$ or $\mathrm{SUSD}^{+}$endometrium-derived mesenchymal stem 
cells (eMSCs), endometrial epithelial stem/progenitor cells, and side population cells (SPs) [2-4], whereas those derived from menstrual blood are called menstrual stem cells (MenSCs).

Endometriosis is defined as the growth and infiltration of endometrial tissue (glands and stroma) outside the uterine cavity with the typical symptom of periodic bleeding, which causes infertility, pain, nodules, and masses [5]. A most widely accepted hypothesis for the pathogenesis of endometriosis first proposed by Sampson et al. in 1927 is that the endometrial glandular epithelium and stromal cells flow within the menstrual blood and enter the pelvic cavity through the fallopian tubes. These cells may invade, grow and spread in the ovary and the adjacent pelvic peritoneum tissues, to eventually form the pelvic endometriosis [6]. This theory is called retrograde menstruation (RM), but it still cannot explain why only $6-10 \%$ of the reproductive age women with RM develop into endometriosis [7]. The concept of stem cells may well explain the low incidence of endometriosis in patients with RM because the abnormal endometrial stem/progenitor cells from just a few patients enter the pelvic cavity to cause endometriotic lesions [2, 8-11].

In this review, we collected the recent advances in the identification and characterization of adult stem/ progenitor cells in female endometrium and summarized the cell-based therapy and immunoregulation of endometrial stem/progenitor cells. We also outlined the signaling pathways and molecular mechanisms involved in endometrial stem/progenitor cell populations. The physiological/pathological roles of bone marrow-derived and endogenous stem/progenitor cells in endometriosis are also analyzed. Finally, we proposed that MenSCs are the most promising candidates for the stem cell-based therapy. The investigation of the molecular mechanisms of stem/progenitor cells in the development of endometriosis may provide some novel strategies for molecular therapy of reproductive and cancerous diseases.

\section{Multiple populations of stem/progenitor cells in endometrium $\mathrm{CD}_{140 b^{+} \mathrm{CD} 146^{+} \text {eMSCs }}$}

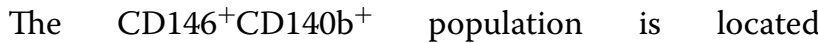
at the perivascular region in both functional and basal layers and can differentiate into osteogenic, myogenic, adipogenic, and chondrogenic lineages, as well as fibroblasts and smooth muscle cells [12-14] (Fig. 1). Mesenchymal stem cell (MSC) markers CD29, CD44, CD73, CD90, CD105, but not endothelial or hemopoietic markers CD31, CD34, and CD45, are expressed in this population

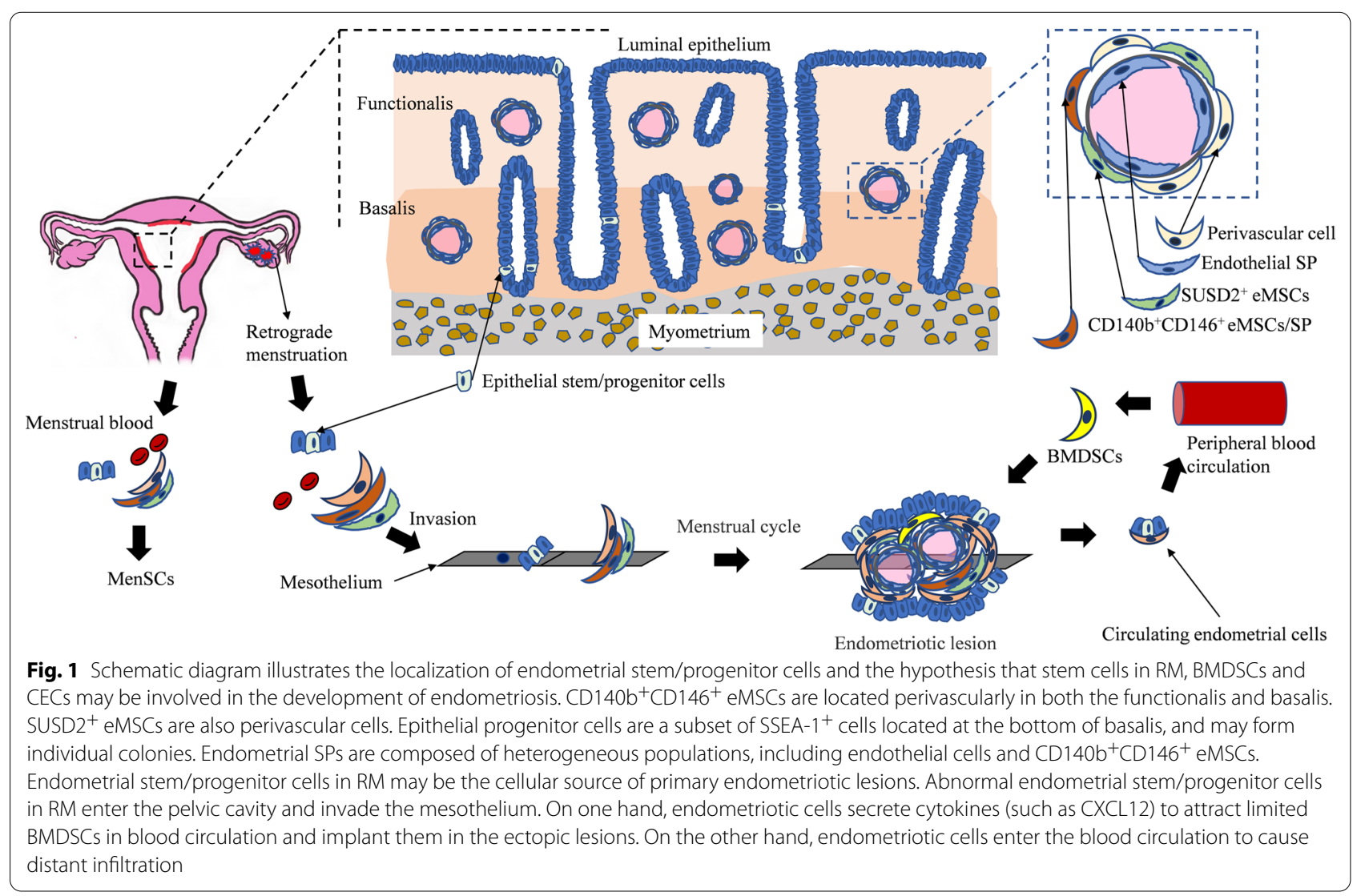


Table 1 Surface marker phenotype and in vitro/in vivo differentiation of human endometrial stem cells

\begin{tabular}{|c|c|c|c|c|}
\hline Cell type & Positive marker & Negative marker & $\begin{array}{l}\text { In vitro and in vivo } \\
\text { differentiation }\end{array}$ & References \\
\hline MenSCs & $\begin{array}{l}\text { CD73, CD90, CD105, CD13, } \\
\text { CD44, CD29, CD9, CD44, } \\
\text { CD41a, CD59 }\end{array}$ & $\begin{array}{l}\text { CD19, CD34, CD45, CD117, } \\
\text { CD130, HLA-DR }\end{array}$ & $\begin{array}{l}\text { Adipocytes, osteocytes, } \\
\text { cardiomyocytes, neurocytes, } \\
\text { respiratory epithelial cells, } \\
\text { endothelial cells, myocytes, } \\
\text { hepatic cells, pancreatic cells, } \\
\text { and germ-like cell }\end{array}$ & {$[42,43]$} \\
\hline $\begin{array}{l}\text { Endometrial SPs of epithelial } \\
\text { origin }\end{array}$ & $\begin{array}{l}\text { CD9, CD90, CD105, CD73, CD45, } \\
\text { CD34, CD31, CD133, stro-1 }\end{array}$ & CD9, CD13 & Adipocytes, osteocytes & {$[96,97]$} \\
\hline $\begin{array}{l}\text { Endometrial SPs from the stro- } \\
\text { mal compartment }\end{array}$ & $\begin{array}{l}\text { Vimentin, CD90, CD73, CD45, } \\
\text { CD34, CD31, CD133, stro-1 }\end{array}$ & CD9, CD13, CD105, ERa, PR & Adipocytes, osteocytes & {$[97]$} \\
\hline SUSD2+ eMSCs & $\begin{array}{l}\text { CD29, CD44, CD73, CD90, } \\
\text { CD105, CD117, CD140b, } \\
\text { CD146, and STRO-1, NTP- } \\
\text { Dase2 }\end{array}$ & CD31, CD45 & $\begin{array}{l}\text { Adipocytes, osteocytes, } \\
\text { chondrocytes, myocytes, } \\
\text { endothelial cells }\end{array}$ & [12] \\
\hline $\mathrm{CD} 140 \mathrm{~b}^{+} \mathrm{CD} 146^{+}$eMSCs & $\begin{array}{r}\text { CD29, CD44, CD73, CD90, } \\
\text { CD105, CD140b, CD146 }\end{array}$ & $\mathrm{CD} 31, \mathrm{CD} 34, \mathrm{CD} 45$ & $\begin{array}{l}\text { Osteocytes, myocytes, adipo- } \\
\text { cytes, chondrocytes, fibro- } \\
\text { blasts and smooth muscle cell }\end{array}$ & {$[12,14,15]$} \\
\hline CD146 ${ }^{+}$cells & $\begin{array}{l}\text { CD10, CD13, CD44, CD73, CD90, } \\
\text { and CD105 }\end{array}$ & $\begin{array}{l}\text { CD31, CD34, CD45, CD56, } \\
\text { CD144, CD9 }\end{array}$ & $\begin{array}{l}\text { Adipocytes, osteoblasts, and } \\
\text { neuron-like cells, glial-like cells }\end{array}$ & {$[19,21]$} \\
\hline Epithelial stem/progenitor cells & N-cadherin, SSEA-1, Axin 2 & & $\begin{array}{l}\text { Entire complement of glandular } \\
\text { lineages, endometrial orga- } \\
\text { noids }\end{array}$ & {$[104,107,150]$} \\
\hline
\end{tabular}

MenSCs menstrual stem cells, SPs side population cells, eMSCs endometrial mesenchymal stem cells

[15] (Table 1). The percentage and clonal capacity of $\mathrm{CD} 140 \mathrm{~b}^{+} \mathrm{CD} 146^{+}$cells are constant at different stages of the menstrual cycle (menstrual, proliferative, and secretory phases). However, compared with the secretory stage, $\mathrm{CD} 140 \mathrm{~b}^{+} \mathrm{CD} 146^{+}$cells from the menstrual endometrium experience more rounds of the self-renewal, suggesting that $\mathrm{CD} 140 \mathrm{~b}^{+} \mathrm{CD} 146^{+}$cells may be activated during menstruation to promote the periodic regeneration of the endometrium. More $\mathrm{CD} 140 \mathrm{~b}^{+} \mathrm{CD} 146^{+}$cells can be detected in the deeper portion of the endometrium than in the superficial layer, but their clonogenic and self-renewal activities remain similarly [16]. Gene expression profiling revealed that 1518 and 762 genes are differentially and significantly expressed between $\mathrm{CD} 140 \mathrm{~b}^{+} \mathrm{CD} 146^{+}$cells and endothelial cells, or between

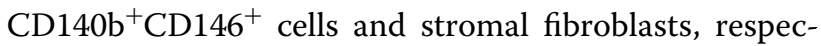

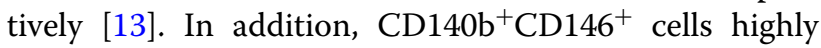
express genes involved in angiogenesis, steroid hormone/ hypoxia responses, immunomodulation, inflammation, cell communication, and proteolysis/inhibition, and display the increased expression of Notch, IGF, TGF$\beta$, Hedgehog, and $G$ protein-coupled receptor signaling molecules compared with $\mathrm{CD} 140 \mathrm{~b}^{+} \mathrm{CD} 146^{-}$cells [13]. Co-culture of endometrial cells (epithelial or stromal) derived from menstruation with $\mathrm{CD} 140 \mathrm{~b}^{+} \mathrm{CD} 146^{+}$ eMSCs enhances the cloning and self-renewal activi-

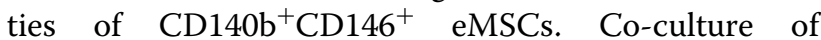
$\mathrm{CD} 140 \mathrm{~b}^{+} \mathrm{CD} 146^{+}$cells with the endometrial niche cell conditioned media containing the high levels of interleukin 6, C-X-C motif ligand 1 (CXCL1) and CXCL5 may increase the proliferation and self-renewal abilities of

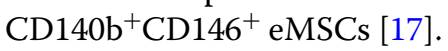

$\mathrm{CD}_{146^{+}}$cells derived from human endometrium can form colony-forming units [18] and differentiate into adipocytes, osteoblasts, neural progenitors, and gliallike cells $[19,20]$ (Table 1). With the help of the collagen-matrigel scaffold on the top of the myometrial smooth muscle cells, human endometrial $\mathrm{CD} 146^{+}$cells may generate endometrial gland-like structures in vitro [21] and express all recognized markers of MSCs, including CD10, CD13, CD44, CD73, CD90, and CD105 [20] (Table 1). Cysteine-rich angiogenesis inducer 61 (CYR61), also called CCN family member 1, is highly expressed in endothelial cells and smooth muscle cells [22] and may play an important role in angiogenesis and tissue repair $[23,24]$. Compared with CD $146^{+} \mathrm{CYR} 61^{-}$, $\mathrm{CD} 146^{+} \mathrm{CYR} 1^{+}$cells can stimulate angiogenesis. The rat endometrium transplanted with $\mathrm{CD} 146^{+} \mathrm{CYR} 61^{+}$ cells appear with higher blood vessel density than that transplanted with $\mathrm{CD} 146^{+}$or $\mathrm{CD} 146^{+} \mathrm{CYR}^{-} 1^{-}$cells. In addition, endometrial injury rats transplanted with $\mathrm{CD} 146^{+} \mathrm{CYR} 1^{+}$cells appear with higher pregnancy rate than control group [20]. 


\section{SUSD2 ${ }^{+}$eMSCs}

SUSD2, a novel marker of eMSCs, is proved particularly effective in the selection of eMSCs [12]. SUSD2 ${ }^{+}$ cells reside predominantly in a perivascular location in both basal and functional layers of endometrium (Fig. 1). $\mathrm{SUSD}^{+}$cells can differentiate into adipocytes, osteocytes, chondrocytes, myocytes, endothelial cells in vitro and produce endometrial stromal-like tissues in vivo (Table 1). Freshly isolated SUSD2 ${ }^{+}$cells express MSC markers including CD29, CD44, CD73, CD90, CD105, CD117, CD140b, CD146, and STRO-1 (Table 1). SUSD2 ${ }^{+}$ cells also express nucleoside triphosphate diphosphohydrolase 2 (NTPDase2), a membrane-expressed enzyme existing in mesenchymal-derived cells, such as pericytes in different tissues and stem cells in adult neurogenic regions $[25,26]$. The expression level and localization of NTPDase2 remain unchanged throughout the menstrual cycle, indicating that the enzyme can be used as a cell marker to improve the separation of eMSCs for regenerative medicine treatment [27].

SUSD2 $^{+}$eMSC seems to be affected by pregnancy and obesity, but not by aging. In the undifferentiated state, SUSD2 ${ }^{+}$-derived cells produce lower levels of various chemokines and inflammatory regulators than SUSD2 ${ }^{-}$cells. However, this is switched after decidualization because these SUSD2 ${ }^{+}$cells are turned into the main source to produce chemokines and cytokines including chemokine (C-C motif) ligand 7, and the leukemia inhibitory factor [28]. SUSD2 ${ }^{+}$cells originated from myometrium and uterine fibroids are featured as MSCs and can also be induced into decidua [29]. Perivascular SUSD2 ${ }^{+}$cells isolated from postmenopausal endometrium also display the characteristics of MSCs, regardless whether the patients receive estrogen pretreatment for the regeneration of endometrium [30]. However, adipocytes may adversely affect endometrial stem cells. Compared with that in women with normal body mass index (BMI), the proportion and cloning efficiency of SUSD2 ${ }^{+}$cells in the endometrium of obese women are significantly reduced [31].

\section{Signaling pathways involved in SUSD2 ${ }^{+}$eMSCs}

In recent years, scientists have gradually paid the attention to the clinical application of endometrial stem cells. The in vitro expansion and stemness maintenance of eMSCs are a major challenge for the current clinical treatment. Studies have found that A83-01, a TGF- $\beta$ receptor inhibitor, can maintain SUSD2+ eMSCs proliferation, clonogenicity, and function through the

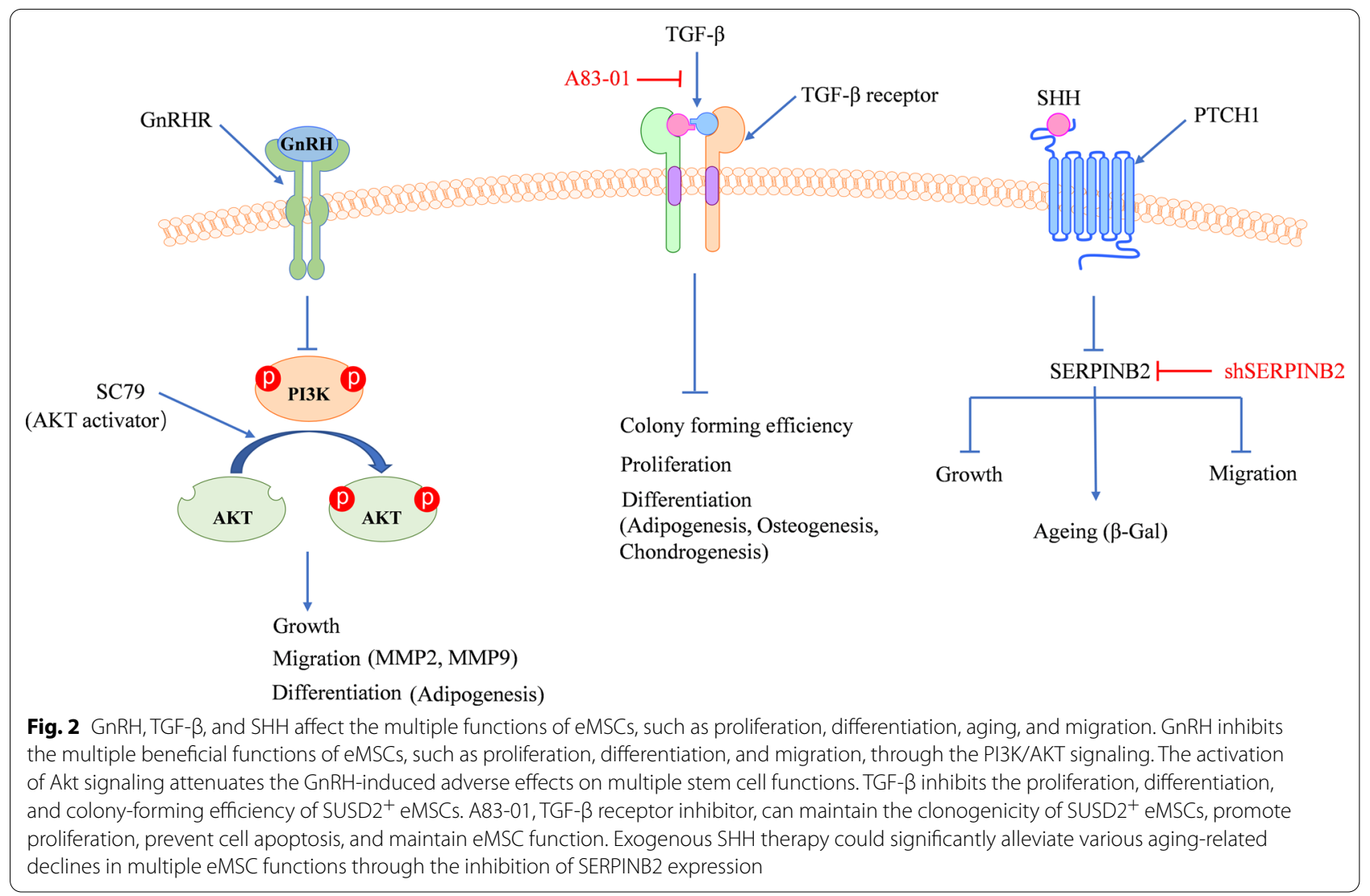


inhibition of TGF- $\beta R$ signaling [32, 33] (Fig. 2). The expression of genes associated with anti-inflammatory response, angiogenesis, cell migration and proliferation can be promoted by A83-01 in SUSD2 ${ }^{+}$eMSCs [34].

Long-term GnRH exposure of eMSCs may be responsible for the relatively low rate of in vitro fertilization (IVF) positive pregnancy outcomes. Unlike terminally differentiated fibroblasts, SUSD2 ${ }^{+}$eMSCs express abundant GnRH receptors. GnRH inhibits the multiple beneficial functions of eMSCs, such as proliferation, differentiation and migration, through the PI3K/Akt signaling pathway [35] (Fig. 2).

The Sonic hedgehog (SHH) signaling typically functions in morphogenesis during the embryonic development [36]. In addition, the decreased SHH signal integrity of local eMSCs may be a potential factor for the decreased regeneration of ageing endometrium. The activity of $\mathrm{SHH}$ is decreased significantly with ageing, but the exogenous SHH therapy may significantly alleviate the various ageing-associated declines. SERPINB2 is a major regulator for the SHH signal transduction during senescence, whereas the senescence of stem cells may enhance the expression of SERPINB2, which in turn mediates the role of $\mathrm{SHH}$ to attenuate the senescence-induced dysfunction of eMSCs [37] (Fig. 2).

\section{SUSD2 ${ }^{+}$eMSCs in immunity and tissue engineering}

Mesenchymal stem cells (MSCs) from other tissues, such as bone marrow, umbilical cord, and adipose tissues, inhibit the proliferation of $\mathrm{T}$ cells, $\mathrm{B}$ cells, natural killer cells (NK), and dendritic cells (DCs) to induce cell cycle arrest through the mechanisms associated with IL-10, prostaglandin E2, TGF- $\beta 1$, and regulatory T cells (Tregs) [38]. Although SUSD2 ${ }^{+}$eMSCs inhibit the mitogeninduced lymphocyte proliferation in a dose-dependent manner, blocking of the mouse IL-10 receptors or the prostaglandin production dose not inhibit lymphocyte proliferation. Despite the reduction of Tregs, endometrial SUSD2 ${ }^{+}$cells continue to inhibit lymphocyte proliferation in the presence of TGF- $\beta$ receptor inhibitors [39]. Therefore, the inhibition of the mitogen-induced lymphocyte proliferation by SUSD2 ${ }^{+}$cells occurs through an uncertain mechanism different from that of MSCs from other tissues (Fig. 3A). Moreover, the systemic
A

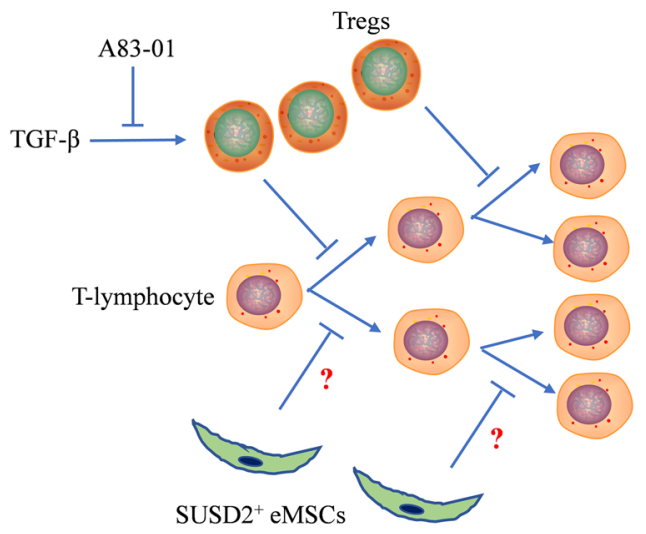

B

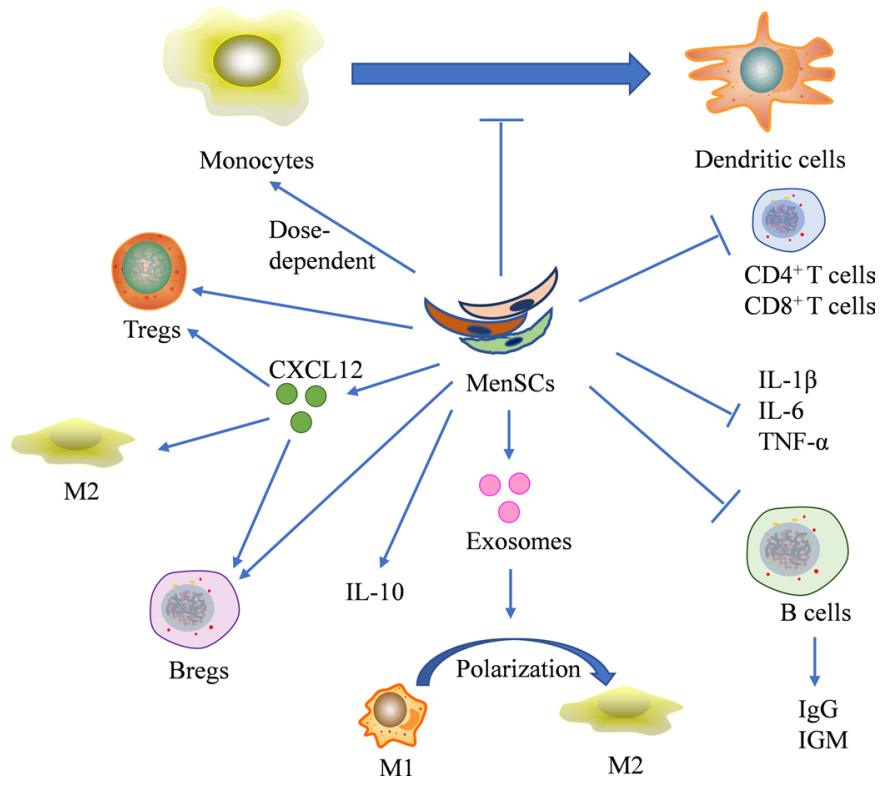

Fig. 3 Roles of SUSD2 ${ }^{+}$eMSCs and MenSCs in immunity. A TGF- $\beta$ promotes the differentiation of Tregs that inhibit T-lymphocyte proliferation. A83-01 increases the T-lymphocyte proliferation through the inhibition of the TGF- $\beta$ signaling-dependent Treg differentiation, but SUSD2 ${ }^{+}$eMSCs continue to inhibit the lymphocyte proliferation via an uncertain mechanism independent of the TGF- $\beta$ signaling from that of MSC from other tissues. B MenSCs inhibit the phenotypic differentiation of human peripheral blood monocytes into immature and mature DCs. MenSCs can also affect the proliferation of monocytes in a dose-dependent manner. In vivo studies, after the intravenous injection of MenSCs, the proportion of $\mathrm{CD} 4^{+}$and $\mathrm{CD} 8^{+} \mathrm{T}$ cells in spleen was significantly down-regulated and the percentage of $\mathrm{CD} 4^{+} \mathrm{CD} 25^{+} \mathrm{Foxp} 3^{+}$regulatory $T$ cells (Treg) and Breg $\left(C D 19^{+} \mid \mathrm{L}-10^{+}\right)$in spleen was significantly up-regulated. The serum levels of $\mathrm{IL}-1 \beta, \mathrm{LL}-6$, and TNF-a in mice receiving MenSCs transplantation are lower, but the expression level of IL-10 is higher. CXCL12 secreted by MenSCs also increases the percentage of Treg, Breg, and M2 cells. MenSC-derived exosomes can resolve inflammation through the induction of the M1-M2 macrophages polarization. MenSCs treatment may inhibit the proliferation of $\mathrm{B}$ cells to reduce the production of $\lg \mathrm{M}$ and $\lg \mathrm{G}$ antibodies 
administration of endometrial SUSD2 ${ }^{+}$cells dose not inhibit the swelling of the T cell-mediated skin inflammation. Although endometrial SUSD2 ${ }^{+}$cells can alter the immune response, their immunoregulatory pool may not be sufficient to suppress the certain $\mathrm{T}$ cell-mediated inflammatory events [39].

Animal studies demonstrate that SUSD2 ${ }^{+}$eMSCs can also modify immune responses to the implanted mesh [39]. Seeding of eMCSs in scaffolds can promote the formation and reconstruction of neo-tissues [40, 41]. The eMSCs alter the growth of collagen and organization around the mesh filaments of the scaffold to affect the physiologically relevant tensile properties of the scaffold-tissue complex. The stiffness of scaffolds seeded with eMSCs on initial stretching can be significantly alleviated. In addition, the scaffold is an appropriate platform for eMSCs delivery, proliferation, and differentiation, with the better biocompatibility and the capacity to regenerate neo-tissues, which may be a promising application in the clinical mesh repair of pelvic organ prolapse (POP) to reduce the excessive scar tissue formation induced by foreign body reactions and to relieve the in vivo poor mechanical compliance.

\section{Menstrual stem cells}

Menstrual stem cells (MenSCs) were first identified from menstrual blood in 2007, which can effectively propagate for over 68 population doublings with normal karyotype [42]. MenSCs express markers CD29, CD9, CD13, CD44, CD41a, CD73, CD59, CD90, and CD105 but not CD19, CD34, CD45, CD117, CD130, or HLA-DR [42, 43] (Table 1). MenSCs partially (over 50\%) express the pluripotency marker SSEA-4, but not Oct-4. MenSCs can differentiate into adipocytic [44], osteogenic [45], cardiomyocytic [46], and neurocytic lineages [47], as well as respiratory epithelial, endothelial, myocytic, hepatic [48], germ-like [49, 50], and pancreatic cells [42, 51] (Table 1). Replacement of fetal bovine serum with human platelet derivatives can promote the differentiation of MenSCs into osteoblasts [52]. The mitotically inactivated MenSCs are ideal feeder cells for the human embryonic stem cell lines C612 and C910 [43].

\section{MenSCs in regenerative medicine and tissue engineering}

MenSCs population is one of the clinically accessible sources of stem cells with great potential in regenerative medicine. MenSCs are abundant in sources with excellent proliferation and autotransplantation capabilities and can be collected regularly and noninvasively. In addition, MenSCs have a higher proliferation ability than that of BMSCs [53]. Most importantly, any significant side effects including acute, subchronic, or chronic poisoning, infection, tumorigenesis, or endometriosis has not been reported either in preclinical studies or in clinical studies during the treatments of various diseases with MenSCs over the past yeas [54-56] (Table 2).

Table 2 Some of the disorders could be (or already are) treated by MenSCs

\begin{tabular}{|c|c|c|}
\hline Disorder & Subjects & References \\
\hline \multirow[t]{2}{*}{ IUA } & Human & {$[57]$} \\
\hline & Rat model & [151] \\
\hline Endometrial injury & Mice model & [152] \\
\hline \multirow[t]{2}{*}{ Premature ovarian failure } & Rat model & {$[58]$} \\
\hline & Mice model & {$[59,78]$} \\
\hline \multirow[t]{2}{*}{ Liver failure } & Mice model & {$[60-62]$} \\
\hline & Pig model & [153] \\
\hline Liver fibrosis & Mice model & [154] \\
\hline Experimental stroke & In vitro stroke model of oxygen glucose deprivation & [63] \\
\hline Pulmonary fibrosis & Mice model & {$[64,65]$} \\
\hline ARDS & Patients with H7N9-induced ARDS & {$[71]$} \\
\hline Myocardial infarction & Rat model & {$[46,68]$} \\
\hline Cardiac allograft & Mice model & {$[67,90]$} \\
\hline Alzheimer's disease & Mice model & {$[69]$} \\
\hline Acute lung injury & Mice model & {$[70]$} \\
\hline Renal ischemia reperfusion injury & Mice model & {$[72]$} \\
\hline Type 1 diabetes & Mice model & {$[75]$} \\
\hline Chronic nonhealing wounds & Diabetic mice model & {$[74]$} \\
\hline Sciatic nerve injury & Rat model & [73] \\
\hline
\end{tabular}

MenSCs menstrual stem cells, IUA intrauterine adhesion, ARDS acute respiratory distress syndrome 
Existing studies have found that MenSCs therapy may be an attractive alternative approach for intrauterine adhesion (IUA) [57], premature ovarian failure (POF) [58, 59], liver failure [60-62], experimental stroke [63], pulmonary fibrosis [64, 65], cardiac diseases [66, 67], myocardial infarction [46, 68], Alzheimer's disease [69], acute lung injury [70], acute respiratory distress syndrome [71], renal ischemia reperfusion injury [72], sciatic nerve injury [73], chronic nonhealing wounds [74], and type 1 diabetes [75] (Table 2).

Studies reported that MenSCs may be used for patients with severe IUA. MenSCs co-cultured with endometrial stromal cells (ESCs) promote the proliferation and wound repair of ESCs, down-regulate the expression of

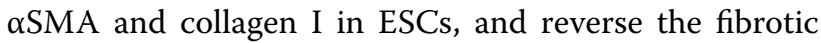
gene expression in ESCs induced by TGF- $\beta$ through the Hippo/TAZ signaling pathway [76]. Intrauterine transplantation of MenSCs in the IUA rat model demonstrate that the endometrial pathology and uterine fertility of the rat are significantly improved [77]. Human autologous MenSCs transplantation may significantly promote the endometrial morphology regeneration and functional recovery in patients with severe IUA, which thereby helps some patients achieve a positive pregnancy [57].

MenSCs with properties of high survival rate in vivo and easy access make them very useful for stem cell transplantation in POF therapy. By two-dimensional culture and 3D scaffold culture system, MenSCs can differentiate into germ-like cells in vitro $[49,50]$. MenSCs transplantation increases the body weight of POF mice, improves the estrus cycle, and restores the fertility of POF mice [78]. The transplanted MenSCs can be detected in the ovarian stroma and survive in the ovaries of POF mice for at least 14 days $[59,78]$, and can be differentiated into granulosa cells and traced to two months in the ovaries of POF rats [58]. The ovaries receiving MenSCs transplantation express the higher levels of ovarian reserve markers $(\mathrm{AMH}$, inhibin $\alpha / \beta$, and follicle-stimulating hormone receptor) and increase the ovarian weight, the plasma E2 level, and the normal follicle counts [59].

The application of MenSCs in tissue engineering is also promising. A wide variety of $3 \mathrm{D}$ scaffolds has been applied to induce differentiation and co-culture of MenSCs. On the nanofiber scaffolds with the specific growth and differentiation factors, MenSCs may be differentiated into chondrocytes to anchor firmly on the highly porous scaffold, and to penetrate and spread on the scaffold. The scaffold contains an extensive cartilage-like extracellular matrix whose glycosaminoglycan content is about $50 \%$ higher than that of the 2D culture system through which MenSCs differentiated [79]. On the 3D wet-electrospun poly (lactic acid)/multi-wall carbon nanotube scaffold, MenSCs can be differentiated into germ-like cells [50].
Based on the bilayer amniotic membrane/nano-fibrous fibroin scaffold, MenSCs can be differentiated into keratinocyte like cells in the presence of keratinocytes derived from human foreskin [80]. In the 3D co-culture system of mouse preantral follicles and human MenSCs, the follicular growth indices are significantly increased, including survival rate, diameter and antrum formation as well as the rate of in vitro maturation rate [81].

\section{Interaction of MenSCs with immune cells}

MenSCs interact with a variety of immune cells and participate in the regulation of cellular immunity and humoral immunity (Fig. 3B). Menstrual blood can be used not only as a source of MenSCs, but also as a source of DCs. Monocytes in menstrual blood can be induced into DCs by a two-step protocol [82]. DCs, the professional antigen-presenting cells, may form an indispensable interface between the innate sensing of pathogens and the activation of adaptive immunity, which thereby enables DCs to be used as a novel and promising immunetherapeutic approach for cancer, persistent infection and autoimmune diseases treatment [83-85]. Similar to SUSD2 $^{+}$eMSCs, MenSCs inhibit the optimal phenotypic differentiation of human peripheral blood monocytes (PBMCs) into immature and mature DCs, in which IL-6 and IL-10 may play an important role [86]. Moreover, MenSCs may also affect the proliferation of monocytes in a dose-dependent manner [87]. The immunosuppressive effects of MenSCs on PBMCs, CD4 $4^{+} \mathrm{IFN}-\gamma^{+}$, and $\mathrm{CD} 8^{+} \mathrm{IFN}-\gamma^{+}$cells are weaker than those of BMDSCs, but MenSCs appear with a higher capacity to migrate into the intestine and liver [88].

In vivo studies showed that MenSCs may protect mice liver from acute injury through the anti-inflammatory and immunomodulatory effects. In the mice model with acute injury liver, the proportion of $\mathrm{CD}^{+}$and $\mathrm{CD} 8^{+} \mathrm{T}$ cells in spleen was significantly down-regulated after intravenous injection of MenSCs, while the percentage of $\mathrm{CD} 4^{+} \mathrm{CD} 25^{+}$Foxp $3^{+}$Tregs in spleen was significantly up-regulated. Additionally, the splenic DCs in MenSCstreated mice displayed a significant decrease of the MHCII expression. The serum and liver levels of IL-1 $\beta$, IL-6, and TNF- $\alpha$ in mice receiving MenSCs transplantation are lower, but the expression level of IL-10 is higher [60]. In the colitis mice model, the treatment with MenSCs mainly regulated the response of B-lymphocytes, whereas the intravenous injection of MenSCs decreased the percentage of immature plasma cells in spleen and IgG deposition in colon but increased the secretion of IL-10 and the production of Bregs $\left(\mathrm{CD} 19^{+} \mathrm{IL}-10^{+}\right)$[89]. On wound-healing process, MenSCs-derived exosomes can attenuate inflammation through the induction of the M1-M2 macrophage polarization [74]. 
The therapeutic function of MenSCs used to alleviate the antibody-mediated allograft rejection can be partly attributed to the cellular immunity regulation [67] and the humoral immunity suppression [90]. The MenSCmediated therapy can prolong the survival of the mice receiving cardiac allotransplantation due to the decrease of IgM and IgG deposition and the circulation of the antidonor antibodies secreted by $\mathrm{CD} 19^{+} \mathrm{B}$ cells. In addition, by ex vivo stimulation, because the proliferation of $\mathrm{B}$ cells from the MenSC-treated heart transplant recipients is impaired, and the production of IgM and IgG antibodies is reduced [90]. Stromal-cell-derived factor-1 (SDF-1), also known as CXCL12, can be secreted in a substantial amount by MenSCs. The MenSC-mediated therapy can induce immunosuppression and donor-specific allograft tolerance in which the SDF-1 secreted by MenSCs plays important roles. Based on MenSCs therapy, SDF-1 can reduce the antibody-mediated rejection and acute cellular rejection to increase the percentages of Tol-DC $\left(\mathrm{CD} 11 \mathrm{c}^{+} \mathrm{MHC}\right.$ class $\left.\mathrm{II}^{+}\right)$, Treg $\left(\mathrm{CD} 4^{+} \mathrm{CD} 25^{+} \mathrm{Foxp}^{+}\right)$, Breg $\left(\mathrm{CD} 19^{+} \mathrm{IL}-10^{+}\right)$, and $\mathrm{M} 2\left(\mathrm{CD}^{+} 8^{+} \mathrm{CD} 206^{+}\right)$cells, and to reduce the percentage of total macrophages [67]. As easily accessible and expandable stem cells, MenSCs are worthy of the researchers' attention for their functions in the regulation of the immune system-related cells and humoral immunity.

\section{Side population cells}

Side population cells (SPs) are considered a universal marker for adult stem cells in mammalian species. This phenotype results from the high expression of plasma membrane transporters (such as ABCG2), which transports the DNA-binding dye Hoechst 33,342 out of the cell [91]. SPs were first isolated from normal human endometrial cells by Kato et al. in 2007 and can be differentiated into gland- and stromal-like cells [92]. Human endometrium contains approximately $1-7 \%$ SPs in freshly isolated human endometrial at various stages, including proliferative phase [93], secretory phase and decidual of early pregnancy $[94,95]$. Most SPs in the endometrium are resting cells in vivo, but during the proliferative phase, a small number of SPs become active to be differentiated into endometrial cells [93, 94]. SPs are located at the vascular endothelium cells lining blood vessels in both the functionalis and the basalis of the endometrium [94] (Fig. 1).

Specific markers have been identified for SPs (Table 1). Endometrial SPs are composed of heterogeneous populations, with endothelial cell markers (CD31), hematopoietic cell markers (CD34 and CD45), the epithelial cell marker EMA and mesenchymal stem cell markers (CD90, CD105, and CD146) [94, 96, 97]. The enrichment of endothelial and $\mathrm{CD} 146^{+} \mathrm{CD} 140 \mathrm{~b}^{+}$eMSCs suggests that the endometrial SPs play a role in angiogenesis during the endometrial regeneration [98]. However, SPs in human decidua of early pregnancy are negative for CD13, CD34, and CD45, but about 95\% of SP cells in human decidua are $\mathrm{CD}^{-} 1^{-} \mathrm{CD} 146^{-}$[99] (Table 1). No difference in the percentage of SUSD2 ${ }^{+}$cells exist between the endometrial SP and non-SP components, but CD140b ${ }^{+}$ $\mathrm{CD}_{146^{+}}$cells are much more abundant in endometrial SPs than in non-SP components [100]. With the greater colony-forming efficiency than non-side population cells [94], SPs can be differentiated into various types of endometrial cells, such as stroma, glandular epithelium, and endothelium cells [93], adipocytes and osteoblasts [96, 101]. SPs also rebuild the well-organized endometrial tissues and glandular structures in vivo [93, 96, 97, 100, $102]$.

Although the endometrial SPs are featured with the excellent self-renewal and differentiation abilities, the dynamic labeling is technically difficult to be performed, the co-labeling with other markers is unreliable, the Hoechst dye is toxic to cells, and flow cytometry sorting damages cells $[14,103]$. Therefore, the heterogeneity of the SPs and their isolation method hinder their clinical applications.

\section{Endometrial epithelial stem/progenitor cells}

Endometrial epithelial progenitor cells were first isolated by Gargett et al. [15]. Individual colonies in the differentiation induction medium are characterized as adult stem cells by analysis of the self-renewal, differentiation, and high proliferative potential of single epithelial. The stage-specific embryonic antigen-1 (SSEA-1), as a marker of human endometrial basal glandular epithelial cells, is used to distinguish the epithelium of basalis from functionalis $[104,105]$ (Fig. 1). SSEA-1 ${ }^{+}$endometrial epithelial cells displaying some characteristics of the basalis epithelium and the higher telomerase activity may produce a higher number of endometrial gland-like spheroids than SSEA- $1^{-}$endometrial epithelial cells in $3 \mathrm{D}$ culture system.

Recently, through in vivo lineage tracking, researchers found that the endometrial epithelium maintains the continuous self-renew during the development, normal growth, and regeneration of the whole life, and demonstrated that a multipotent endometrial epithelial stem cells with naturally occurring somatic mitochondrial DNA mutations (CCO gene) can regenerate the entire complement of glandular lineages [106, 107]. Axin2, a key negative regulator of the Wnt signaling pathway is expressed in the stem cells of various organs [108], and is also identified as a marker of long-lived bipotent epithelial progenitors that reside in endometrial glands [107]. Cytoplasmic Axin2 is also expressed 
in the functionalis of proliferative and secretory endometrial glandular epithelia from premenopausal women. In contrast, the nuclear Axin2 expression is observed in the proliferative and secretory basalis of premenopausal and postmenopausal endometrial epithelia [105]. Axin2expressing glandular cells express the known stem cell markers, such as Lgr5, Trop2 and Sox9 to fuel endometrial epithelial growth and regeneration in vivo. In addition, Axin $2^{+}$cells can form fully functional endometrial organoids in vitro [107]. The above findings seem to provide evidence for the involvement of the mesenchymalto-epithelial transition (MET) in the maintenance and regeneration of the uterine epithelium [109]. However, a recent cell fate tracing study found that the conclusive evidence for the conversion of mesenchymal cells to epithelial cells in adult uterine is lacking. The study of the embryonal cell lineage tracing with reporters driven by mesenchymal cell marker genes of the female reproductive tract (AMHR2, CSPG4, and PDGFR $\beta$ ) showed that these reporters are also expressed in some oviductal and uterine epithelial cells at birth [110].

The endometrial epithelial stem cell population of mouse residing in the intersection zone between luminal and glandular epithelial compartments is also identified by in vivo lineage tracking in which the tissue distribution allow the bipotent endometrial epithelial stem cells to be differentiated bidirectionally into luminal epithelial cells and glandular epithelial cells and to maintain the homeostasis and regeneration of the mouse endometrial epithelium under physiological conditions [111]. However, no labeled epithelial cells were found in any fallopian tubes or uterine epithelium after the mesenchymal cell labeling is induced in adult mice, indicating that no definitive evidence of MET happens in the fallopian tubes and uterine epithelium in murine [110]. Very small embryonic-like stem cells (VSELs) are recently identified in mouse uterine [112], but they are still controversial [113] because without the sufficient functional analysis to prove their pluripotency until now [4].

\section{Participation of endometrial stem/progenitor cells in the origin and development of endometriosis}

Endometriosis is characterized by the development of endometrial tissues outside the uterus to cause pain and infertility. Due to the lack of effective biomarkers, endometriosis is usually not diagnosed until the first onset of the disease a few years later. So far, most of the existing treatments are non-therapeutic [8]. Until the beginning of the twenty-first century, some scholars suspected that endometriosis may be a stem cell-related disease, because less differentiated endometrial cells in RM may be the cellular source of primary endometriotic lesions $[8,114$, 115]. Endometrial stem/progenitor cells with the altered molecular properties reflux into the pelvic cavity via RM, where they adhere and form ectopic lesions. The prevalence of shed basalis fragments in the menstrual blood of women with endometriosis is significantly higher than that in the healthy control menstrual blood [8]. The endometrium of endometriotic lesions displays a cyclical pattern similar to the basalis and presents the same cyclical pattern of ER and PR expression as the deep basalis. The expression of adult stem cell markers Musashi-1 [116], OCT4, SOX15, SOX2 [117, 118], C-kit [119], Notch and Numb [120], and the corneal epithelial progenitor cell marker importin13 [121] is significantly higher in endometriotic lesions than in normal endometrium. The peripheral lymphocytes from endometriosis patients are detected with longer telomeres than those from healthy controls [122]. Moreover, the expression of SSEA-1 in ectopic epithelial cells is similar to that in eutopic basalis epithelium [104, 123]. These data support the concept of a stem cell origin of endometriosis that the presence of the abnormally detached basalis endometrium fragments in the RM is considered as the main cause of endometriosis (Fig. 1).

\section{Peritoneal microenvironment interacts with ectopic cells in patients with endometriosis}

Endometriosis alters the peritoneal microenvironment of women, in which the immune response, angiogenesis, cell proliferation, cell adhesion, and apoptosis are uniquely regulated in peritoneal fluid (PF). A specific protein expression pattern is present in $\mathrm{PF}$ with deep infiltrating endometriosis (DIE) compared in PF with non-DIE [124]. The detached endometrial fragments flow into the pelvic cavity, where they directly interact with cytokines in PF [125] to secrete chemokines [126] and to form a feedforward loop [127], which eventually induces the infiltration of immune cells and BMDSCs [128]. Seventy-four cytokines are increased and 4 cytokines are decreased in PF from endometriosis patients compared with those in healthy control group [125]. Among these cytokines, activin A is significantly increased in PF from endometriosis group, whereas ALK4 (activin A-specific receptor) is increased in ectopic endometrial-derived SUSD2 ${ }^{+}$eMSCs [129]. In addition, the levels of Activin A secreted by glandular cells and stromal cells are significantly higher in the eutopic endometrium of endometriosis patients than in the eutopic endometrium of healthy controls [130]. The expression of the connective tissue growth factor (CTGF) in SUSD2 ${ }^{+}$eMSCs may be promoted by Activin A through the binding of Smad2/3 to the CTGF promoter to induce the myofibroblast differentiation of SUSD2 ${ }^{+}$eMSCs. Endometriotic lesions may be enhanced by Activin A through the increased IL-6, IL-8, and TNF- $\alpha$ in the ascites of endometriosis mice models [131, 132]. Inhibition of the activin A pathway prevents 
the myofibroblast differentiation of SUSD2 ${ }^{+}$eMSCs and improves fibrosis in endometriosis mice [129]. Endometriotic cells interact with the abnormal peritoneal microenvironment of patients with endometriosis. The ectopic cells secrete inflammatory factors that may remodel the peritoneal microenvironment, and in turn, various cytokines in PF exert their function on the endometriotic cells.

\section{Abnormal expression profiles of endometrial stem cells from endometriosis patients}

Ectopic eMSCs from endometriosis patients display stronger abilities of proliferation, migration, and angiogenesis than eutopic eMSCs from the same individual or from healthy controls [133]. The expression profiles of adenomyosis-derived mesenchymal stem cells (AMSCs) are different from those of eMSCs and BMSCs. Compared with eMSCs, the expression of cyclooxygenase-2 (COX-2) in AMSCs is significantly increased, and inhibition of COX-2 blocks the migration and invasion of AMSCs and induces their apoptosis [134].

$\mathrm{CD}_{3}{ }^{+} \mathrm{CD} 90^{+} \mathrm{CD} 105^{+}$endometrial stem cells $\left(\mathrm{SCs}^{+}\right)$ from normal, ectopic and eutopic endometrium display a significantly higher level of SUSD2 ${ }^{+}$with cloning efficiency and sphere formation capacity than $\mathrm{SCs}^{-}$. Compared with in eutopic endometrium $\mathrm{SC}^{+}$samples, the expression of PTEN, ARID1A, and TNF $\alpha$ from paired-ectopic samples is significantly down-regulated. Analysis of the hierarchical and multivariate clustering from both $\mathrm{SC}^{+}$and tissue cohorts revealed the abnormal expression of stemnessrelated and cancer-related genes such as KIT, HIF $2 \alpha$, and E-Cadherin in 4 of 30 ectopic samples. C-kit is expressed higher in the endometrial glandular cells of the women with endometriosis than in the endometrial glandular cells of the women without endometriosis [119]. Therefore, it is speculated that the changes in stemness-associated genes may be linked to the development of endometriosis [135].

MenSCs from women with and without endometriosis display different phenotypic and functional characteristics [136]. MenSCs from the endometriosis (E-MenSCs) women appear with the higher expression of CD9, CD10, and CD29 and the higher proliferation and invasion potentials than MenSCs from the non-endometriosis (NE-MenSCs) women. The expression of the indoleamine 2,3-dioxygenase-1 (IDO1) and COX-2 in E-MenSCs is higher than in NE-MenSCs. In addition, the supernatants of E-MenSCs contain the higher levels of IFN- $\gamma$, IL-10, and the monocyte chemoattractant protein 1 than those of NEMenSCs. These findings indicate that MenSCs may play an alternative role in the pathogenesis of endometriosis, which further supports the stem cell theory of endometriosis with RM.

\section{Stem/progenitor cells or stem-like cells of extrauterine origin promote endometriosis}

A study reported that a few of stromal cells and epithelial cells from doner mouse endometrial tissues were traced in the ectopic implant lesions of the recipient mice after 10 weeks of transplantation, indicating that the cells from the extrauterine origin may also promote the development of ectopic endometrium [137].

BMDSCs participate in the pathogenesis of endometriosis to promote the development of the disease [138] (Fig. 1). BMDSCs implanted into ectopic endometrial and endometriotic lesions display the properties of stromal and epithelial cells [137, 139], while the cytokines secreted by the implanted BMDSCs promote the proliferation of ectopic endometrial cells [138]. In turn, the endometriotic cells also stimulate the BMDSCs differentiation and increase the expression of PD-1 in $\mathrm{T}$ cells possibly through the paracrine signaling [140]. The ectopic endometrium competes with the eutopic endometrium for the limited supply of BMDSCs in blood circulation and the depletion of normal BMDSCs flux to the uterus. In addition, stem cells migrate from the endometriotic lesions to the uterus, to induce the dysfunction of the eutopic endometrium [141]. 17 $\beta$-Estradiol can promote the chemotaxis and migration of BMDSCs by upregulating the secretion of chemokine SDF-1 $\alpha$ [142]. In a mouse endometriosis model, bazedoxifene [139], an estrogen receptor modulator, administered with the conjugated estrogens and letrozole [143] (aromatase inhibitor) not only alleviated the lesions of endometriosis, but also dramatically reduced the recruitment of BMDSCs to the lesions and restore the stem cell engraftment of the uterine endometrium.

Endometrial stromal cells express the chemokine CXCL12, while BMDSCs express CXCR4, the receptor of CXCL12 [144]. In human and mice models of endometriosis, higher levels of CXCL12 and CXCR4 were detected in ectopic lesions and serum than those in healthy controls [145]. The fluctuation of CXCL12 concentration produces a chemical gradient that guides the migration of stem cells [146]. The chemoattraction of mouse BMDSCs to CXCL12 in the conditioned medium (CM) of endometriotic cells is higher than that in the $\mathrm{CM}$ of eutopic endometrium [145]. Activation of the CXCL12/CXCR4 signaling axis promotes the ectopic lesions to outcompete eutopic endometrium to recruit the limited supply of circulating BMDSCs. Targeting CXCR4 by using the small molecule receptor antagonist AMD3100 reduces the recruitment of BMDSCs into the endometriosis and the size of the endometriosis lesions [147]. Antagonist treatment also reduces the production of pro-inflammatory cytokines and angiogenesis in the lesions of endometriosis [147]. 
Circulating endometrial cells (CECs) were identified in the peripheral blood of all the acknowledged endometriosis stages: minimal, mild, moderate, and severe (Fig. 1). The CECs captured during the menstrual cycle phases display stem cell-like characteristics [148]. CECs are also found in the patients with pelvic endometriosis and spontaneous pneumothorax, with the properties of epithelial, stroma-like, glandular [149], or stem cell-like cells. A reporter found that DsRed ${ }^{+}$ cells can be found in blood of DsRed ${ }^{-}$mice with endometriosis receiving the peritoneal cavity transplantation of DsRed+ mice endometrial tissues. Almost all of CECs originated from endometriosis rather than uterus express CXCR4 and MSCs biomarkers, but not hematopoietic stem cell markers, and contribute to both endometriosis and angiogenesis. Cells originated from endometriosis lesions may migrate and implant in lung tissues and display the abilities of differentiation into adipogenic, osteogenic, and chondrogenic lineages in vitro, indicating a retained multipotency.

Overall, endometrial stem/progenitor cells in menstruation blood (MenSCs) are the most clinically accessible sources of stem cells with a great potential in the regenerative medicine and tissue engineering. The advantages of MenSCs are that they can be collected regularly and noninvasively. MenSCs are also promising candidates in the stem cell therapy for inflammation and immune-related diseases, and may play an immunosuppressive role in the regulation of the cell-mediated immunity and humoral immunity. The bone marrow-derived and endogenous stem/progenitor cells participate in the origin and development of endometriosis. Endogenous stem/progenitor cells with the altered molecular properties from the shedding endometrium fragments may reflux into the pelvic cavity via RM, which may be considered as the main inducer of endometriosis. The ectopic lesions compete with the eutopic endometrium for the limited BMDSCs in blood circulation to induce the establishment of the deep invasive endometriosis. In addition, stem-like cells in ectopic lesions may also enter the peripheral blood circulation and cause distant invasion. The study of the molecular mechanisms of stem/ progenitor cells or stem-like cells in endometriosis may provide some promising targets for molecular therapy of the associated reproductive and cancerous diseases.

\footnotetext{
Abbreviations

eMSCs: endometrial mesenchymal stem cells; SPs: side population cells; MenSCs: menstrual stem cells; BMDSCs: bone marrow mesenchymal stem cells; RM: retrograde menstruation; CFUs: colony-forming units; LRCs: labelretaining cells; ABCG2: ATP-binding cassette transporter G2; Era: estrogen receptor alpha; PR: progesterone receptor; SSEA-1: stage-specific embryonic antigen-1; MSC: mesenchymal stem cell; CXCL1: C-X-C motif ligand 1; CYR61: cysteine-rich angiogenesis inducer 61; NTPDase2: nucleoside triphosphate
}

diphosphohydrolase 2; BMI: body mass index; IVF: in vitro fertilization; SHH: Sonic hedgehog; POP: pelvic organ prolapse; PCL: poly $\varepsilon$-caprolactone; IUA: intrauterine adhesion; ESCs: endometrial stromal cells; POF: premature ovarian failure; DCs: dendritic cells; PBMCs: peripheral blood mononuclear cells; SDF-1: stromal cell-derived factor-1; DIE: deep infiltrating endometriosis; PF: peritoneal fluid; CTGF: connective tissue growth factor; AMSCs: adenomyosis-derived mesenchymal stem cells; COX-2: Cyclooxygenase-2; $\mathrm{SC}^{+}$: $\mathrm{CD} 73^{+} \mathrm{CD}{ }^{+} \mathrm{CD}_{105}{ }^{+}$multipotent stem cell; IDO1: indoleamine 2,3-dioxygenase-1; CECs: Circulating endometrial cells; MET: mesenchymal-to-epithelial transition.

\section{Acknowledgements}

We are grateful to the National Natural Science Foundation of China (81402153 for CR, and 81572553, 81772789 for GY).

\section{Authors' contributions}

YK performed literature search and wrote the first draft of the manuscripts. SY was involved in the revision of the manuscripts. CR and GY were responsible for discussing and revising the content. All authors read and approved the final manuscript.

\section{Funding}

This study was supported by grants from the National Natural Science Foundation of China (81402153 for CR, and 81572553, 81772789 for GY).

Availability of data and materials

Not applicable.

\section{Declarations}

Ethics approval and consent to participate

Not applicable.

\section{Consent for publication}

Not applicable.

\section{Competing interests}

The authors declare that this article has no conflict of interest.

\section{Author details}

${ }^{1}$ Cancer Institute, Fudan University Shanghai Cancer Center, Shanghai 200032, China. ${ }^{2}$ Department of Oncology, Shanghai Medical College, Fudan University, Shanghai 200032, China. ${ }^{3}$ Center for Reproductive Medicine, Shuguang Hospital Affiliated to Shanghai University of Traditional Chinese Medicine, Shanghai 200120, China. ${ }^{4}$ Central Laboratory, The Fifth People's Hospital of Shanghai Fudan University, Shanghai 200240, China.

Received: 16 May 2021 Accepted: 19 July 2021

Published online: 23 August 2021

References

1. Chan RW, Schwab KE, Gargett CE. Clonogenicity of human endometrial epithelial and stromal cells. Biol Reprod. 2004. https://doi.org/10.1095/ biolreprod.103.024109.

2. Gargett CE, Schwab KE, Deane JA. Endometrial stem/progenitor cells: the first 10 years. Hum Reprod Update. 2016. https://doi.org/10.1093/ humupd/dmv051.

3. Bhartiya D. An update on endometrial stem cells and progenitors. Hum Reprod Update. 2016. https://doi.org/10.1093/humupd/dmw010.

4. Gargett CE, Deane JA, Schwab KE. Reply: An update on endometrial stem cells and progenitors by Deepa Bhartiya. Hum Reprod Update. 2016. https://doi.org/10.1093/humupd/dmw011.

5. Yilmaz BD, Bulun SE. Endometriosis and nuclear receptors. Hum Reprod Update. 2019. https://doi.org/10.1093/humupd/dmz005.

6. Sampson JA. Peritoneal endometriosis due to the menstrual dissemination of endometrial tissue into the peritoneal cavity. Am J Obstet Gynecol. 1927. https://doi.org/10.1016/s0002-9378(15)30003-x. 
7. Halme J, Hammond MG, Hulka JF, Raj SG, Talbert LM. Retrograde menstruation in healthy women and in patients with endometriosis. Obstet Gynecol. 1984;64:151-4.

8. Leyendecker G, Herbertz M, Kunz G, Mall G. Endometriosis results from the dislocation of basal endometrium. Hum Reprod. 2002. https://doi. org/10.1093/humrep/17.10.2725.

9. Starzinski-Powitz A, Zeitvogel A, Schreiner A, Baumann R. In search of pathogenic mechanisms in endometriosis: the challenge for molecular cell biology. Curr Mol Med. 2001. https://doi.org/10.2174/1566524013 363168.

10. Gargett CE. Uterine stem cells: what is the evidence? Hum Reprod Update. 2007. https://doi.org/10.1093/humupd/dml045.

11. Maruyama T, Miyazaki K, Masuda H, Ono M, Uchida H, Yoshimura Y. Review: Human uterine stem/progenitor cells_implications for uterine physiology and pathology. Placenta. 2013. https://doi.org/10.1016/j. placenta.2012.12.010.

12. Masuda H, Anwar SS, Buhring HJ, Rao JR, Gargett CE. A novel marker of human endometrial mesenchymal stem-like cells. Cell Transplant. 2012. https://doi.org/10.3727/096368911×637362.

13. Spitzer TL, Rojas A, Zelenko Z, Aghajanova L, Erikson DW, Barragan F, et al. Perivascular human endometrial mesenchymal stem cells express pathways relevant to self-renewal, lineage specification, and functional phenotype. Biol Reprod. 2012. https://doi.org/10.1095/biolreprod.111. 095885.

14. Schwab KE, Gargett CE. Co-expression of two perivascular cell markers isolates mesenchymal stem-like cells from human endometrium. Hum Reprod. 2007. https://doi.org/10.1093/humrep/dem265.

15. Gargett CE, Schwab KE, Zillwood RM, Nguyen HP, Wu D. Isolation and culture of epithelial progenitors and mesenchymal stem cells from human endometrium. Biol Reprod. 2009. https://doi.org/10.1095/biolr eprod.108.075226

16. Xu S, Chan RWS, Ng EHY, Yeung WSB. Spatial and temporal characterization of endometrial mesenchymal stem-like cells activity during the menstrual cycle. Exp Cell Res. 2017. https://doi.org/10.1016/j.yexcr.2016. 11.020 .

17. Xu S, Chan RWS, LiT, Ng EHY, Yeung WSB. Understanding the regulatory mechanisms of endometrial cells on activities of endometrial mesenchymal stem-like cells during menstruation. Stem Cell Res Ther. 2020. https://doi.org/10.1186/s13287-020-01750-3.

18. Schwab KE, Hutchinson P, Gargett CE. Identification of surface markers for prospective isolation of human endometrial stromal colony-forming cells. Hum Reprod. 2008. https://doi.org/10.1093/humrep/den051.

19. Fayazi M, Salehnia M, Ziaei S. Differentiation of human CD146-positive endometrial stem cells to adipogenic-, osteogenic-, neural progenitor-, and glial-like cells. In Vitro Cell Dev Biol Anim. 2015. https://doi.org/10. 1007/s11626-014-9842-2.

20. Li Z, Yan G, Diao Q, Yu F, Li X, Sheng X, et al. Transplantation of human endometrial perivascular cells with elevated CYR61 expression induces angiogenesis and promotes repair of a full-thickness uterine injury in rat. Stem Cell Res Ther. 2019. https://doi.org/10.1186/ s13287-019-1272-3.

21. Fayazi M, Salehnia M, Ziaei S. In-vitro construction of endometrial-like epithelium using CD146(+) mesenchymal cells derived from human endometrium. Reprod Biomed Online. 2017. https://doi.org/10.1016/j. rbmo.2017.05.020.

22. Mo FE, Muntean AG, Chen CC, Stolz DB, Watkins SC, Lau LF. CYR61 (CCN1) is essential for placental development and vascular integrity. Mol Cell Biol. 2002. https://doi.org/10.1128/mcb.22.24.8709-8720.2002.

23. Jun JI, Lau LF. The matricellular protein CCN1 induces fibroblast senescence and restricts fibrosis in cutaneous wound healing. Nat Cell Biol. 2010. https://doi.org/10.1038/ncb2070.

24. Krupska I, Bruford EA, Chaqour B. Eyeing the Cyr61/CTGF/NOV (CCN) group of genes in development and diseases: highlights of their structural likenesses and functional dissimilarities. Hum Genom. 2015. https://doi.org/10.1186/s40246-015-0046-y.

25. Zimmermann $H$, Zebisch $M$, Sträter N. Cellular function and molecular structure of ecto-nucleotidases. Purinergic Signal. 2012. https://doi.org/ 10.1007/s1 1302-012-9309-4

26. Yegutkin GG. Enzymes involved in metabolism of extracellular nucleotides and nucleosides: functional implications and measurement of activities. Crit Rev Biochem Mol Biol. 2014. https://doi.org/10.3109/ 10409238.2014.953627.

27. Trapero C, Vidal A, Rodriguez-Martinez A, Sevigny J, Ponce J, Coroleu $B$, et al. The ectonucleoside triphosphate diphosphohydrolase-2 (NTPDase2) in human endometrium: a novel marker of basal stroma and mesenchymal stem cells. Purinergic Signal. 2019. https://doi.org/ 10.1007/s11302-019-09656-3.

28. Murakami K, Lee YH, Lucas ES, Chan YW, Durairaj RP, Takeda S, et al. Decidualization induces a secretome switch in perivascular niche cells of the human endometrium. Endocrinology. 2014. https://doi.org/10. 1210/en.2014-1370.

29. Patterson AL, George JW, Chatterjee A, Carpenter TJ, Wolfrum E, Chesla DW, et al. Putative human myometrial and fibroid stem-like cells have mesenchymal stem cell and endometrial stromal cell properties. Hum Reprod. 2020. https://doi.org/10.1093/humrep/dez247.

30. Ulrich D, Tan KS, Deane J, Schwab K, Cheong A, Rosamilia A, et al. Mesenchymal stem/stromal cells in post-menopausal endometrium. Hum Reprod. 2014. https://doi.org/10.1093/humrep/deu159.

31. Murakami K, Bhandari H, Lucas ES, Takeda S, Gargett CE, Quenby S, et al. Deficiency in clonogenic endometrial mesenchymal stem cells in obese women with reproductive failure: a pilot study. PLoS ONE. 2013. https://doi.org/10.1371/journal.pone.0082582.

32. Gurung $S$, Werkmeister JA, Gargett CE. Inhibition of transforming growth factor- $\beta$ receptor signaling promotes culture expansion of undifferentiated human endometrial mesenchymal stem/stromal cells. Sci Rep. 2015. https://doi.org/10.1038/srep15042.

33. Gurung S, Deane JA, Darzi S, Werkmeister JA, Gargett CE. In vivo survival of human endometrial mesenchymal stem cells transplanted under the kidney capsule of immunocompromised mice. Stem Cells Dev. 2018. https://doi.org/10.1089/scd.2017.0177.

34. Gurung S, Williams S, Deane JA, Werkmeister JA, Gargett CE. The transcriptome of human endometrial mesenchymal stem cells under TGFbetaR inhibition reveals improved potential for cell-based therapies. Front Cell Dev Biol. 2018. https://doi.org/10.3389/fcell.2018.00164.

35. Park SR, Cho A, Park ST, Park CH, Lim S, Jin M, et al. Double-edged sword of gonadotropin-releasing hormone $(\mathrm{GnRH})$ : a novel role of $\mathrm{GnRH}$ in the multiple beneficial functions of endometrial stem cells. Cell Death Dis. 2018. https://doi.org/10.1038/s41419-018-0892-3.

36. Briscoe J, Thérond PP. The mechanisms of hedgehog signalling and its roles in development and disease. Nat Rev Mol Cell Biol. 2013. https:// doi.org/10.1038/nrm3598.

37. Cho A, Park SR, Kim SR, Nam S, Lim S, Park CH, et al. An endogenous anti-aging factor, sonic hedgehog, suppresses endometrial stem cell aging through SERPINB2. Mol Ther. 2019. https://doi.org/10.1016/j. ymthe.2019.04.019.

38. De Miguel MP, Fuentes-Julián S, Blázquez-Martínez A, Pascual CY, Aller MA, Arias J, et al. Immunosuppressive properties of mesenchymal stem cells: advances and applications. Curr Mol Med. 2012. https://doi.org/ 10.2174/156652412800619950.

39. Yang X, Devianti M, Yang YH, Ong YR, Tan KS, Gurung S, et al. Endometrial mesenchymal stem/stromal cell modulation of T cell proliferation. Reproduction. 2018. https://doi.org/10.1530/rep-18-0266.

40. Edwards SL, Ulrich D, White JF, Su K, Rosamilia A, Ramshaw JA, et al. Temporal changes in the biomechanical properties of endometrial mesenchymal stem cell seeded scaffolds in a rat model. Acta Biomater. 2015. https://doi.org/10.1016/j.actbio.2014.10.043.

41. Su K, Edwards SL, Tan KS, White JF, Kandel S, Ramshaw JAM, et al. Induction of endometrial mesenchymal stem cells into tissue-forming cells suitable for fascial repair. Acta Biomater. 2014. https://doi.org/10.1016/j. actbio.2014.08.031.

42. Meng X, Ichim TE, Zhong J, Rogers A, Yin Z, Jackson J, et al. Endometrial regenerative cells: a novel stem cell population. J Transl Med. 2007. https://doi.org/10.1186/1479-5876-5-57.

43. Zemel'ko VI, GrinchukTM, Domnina AP, Artsybasheva IV, Zenin WV, Kirsanov AA, et al. Multipotent mesenchymal stem cells of desquamated endometrium: isolation, characterization and use as feeder layer for maintenance of human embryonic stem cell lines. Tsitologiia. 2011:53:919-29.

44. Khanmohammadi M, Khanjani S, Edalatkhah H, Zarnani AH, HeidariVala $\mathrm{H}$, Soleimani M, et al. Modified protocol for improvement of 
differentiation potential of menstrual blood-derived stem cells into adipogenic lineage. Cell Prolif. 2014. https://doi.org/10.1111/cpr.12133.

45. Darzi S, Zarnani AH, Jeddi-Tehrani M, Entezami K, Mirzadegan E, Akhondi MM, et al. Osteogenic differentiation of stem cells derived from menstrual blood versus bone marrow in the presence of human platelet releasate. Tissue Eng Part A. 2012. https://doi.org/10.1089/ten. TEA.2011.0386.

46. Hida N, Nishiyama N, Miyoshi S, Kira S, Segawa K, Uyama T, et al. Novel cardiac precursor-like cells from human menstrual blood-derived mesenchymal cells. Stem Cells. 2008. https://doi.org/10.1634/stemcells. 2007-0826

47. Liu Y, Yang F, Liang S, Liu Q, Fu S, Wang Z, et al. N-cadherin upregulation promotes the neurogenic differentiation of menstrual blood-derived endometrial stem cells. Stem Cells Int. 2018. https://doi.org/10.1155/ 2018/3250379.

48. Mou XZ, Lin J, Chen JY, Li YF, Wu XX, Xiang BY, et al. Menstrual blood-derived mesenchymal stem cells differentiate into functional hepatocyte-like cells. J Zhejiang Univ Sci B. 2013. https://doi.org/10. 1631/jzus.B1300081.

49. Lai D, Guo Y, Zhang Q, Chen Y, Xiang C. Differentiation of human menstrual blood-derived endometrial mesenchymal stem cells into oocyte-like cells. Acta Biochim Biophys Sin (Shanghai). 2016. https://doi. org/10.1093/abbs/gmw090.

50. Eyni H, Ghorbani S, Shirazi R, Salari AsI L, Shahram PB, Soleimani M. Three-dimensional wet-electrospun poly(lactic acid)/multi-wall carbon nanotubes scaffold induces differentiation of human menstrual bloodderived stem cells into germ-like cells. J Biomater Appl. 2017. https:// doi.org/10.1177/0885328217723179.

51. Patel AN, Park E, Kuzman M, Benetti F, Silva FJ, Allickson JG. Multipotent menstrual blood stromal stem cells: isolation, characterization, and differentiation. Cell Transplant. 2008. https://doi.org/10.3727/0963689087 84153922.

52. Kazemnejad S, Najafi R, Zarnani AH, Eghtesad S. Comparative effect of human platelet derivatives on proliferation and osteogenic differentiation of menstrual blood-derived stem cells. Mol Biotechnol. 2014. https://doi.org/10.1007/s12033-013-9698-9.

53. Khanmohammadi M, Khanjani S, Bakhtyari MS, Zarnani AH, Edalatkhah $\mathrm{H}$, Akhondi MM, et al. Proliferation and chondrogenic differentiation potential of menstrual blood- and bone marrow-derived stem cells in two-dimensional culture. Int J Hematol. 2012. https://doi.org/10.1007/ s12185-012-1067-0.

54. Liu Y, Niu R, Yang F, Yan Y, Liang S, Sun Y, et al. Biological characteristics of human menstrual blood-derived endometrial stem cells. J Cell Mol Med. 2018. https://doi.org/10.1111/jcmm.13437.

55. Chang QY, Zhang SW, Li PP, Yuan ZW, Tan JC. Safety of menstrual blood-derived stromal cell transplantation in treatment of intrauterine adhesion. World J Stem Cells. 2020. https://doi.org/10.4252/wjsc.v12.i5. 368.

56. Domnina AP, Novikova PV, Lyublinskaya OG, Zenin WV, Fridlyanskaya II, Mikhailov VM, et al. Mesenchymal stem cells with irreversibly arrested proliferation stimulate decidua development in rats. Exp Ther Med. 2016. https://doi.org/10.3892/etm.2016.3671.

57. Tan J, Li P, Wang Q, Li Y, Li X, Zhao D, et al. Autologous menstrual bloodderived stromal cells transplantation for severe Asherman's syndrome. Hum Reprod. 2016. https://doi.org/10.1093/humrep/dew235.

58. Noory P, Navid S, Zanganeh BM, Talebi A, Borhani-Haghighi M, Gholami $\mathrm{K}$, et al. Human menstrual blood stem cell-derived granulosa cells participate in ovarian follicle formation in a rat model of premature ovarian failure in vivo. Cell Reprogram. 2019. https://doi.org/10.1089/cell.2019. 0020.

59. Liu T, Huang Y, Zhang J, Qin W, Chi H, Chen J, et al. Transplantation of human menstrual blood stem cells to treat premature ovarian failure in mouse model. Stem Cells Dev. 2014. https://doi.org/10.1089/scd.2013. 0371.

60. Lu S, Shi G, Xu X, Wang G, Lan X, Sun P, et al. Human endometrial regenerative cells alleviate carbon tetrachloride-induced acute liver injury in mice. JTransl Med. 2016. https://doi.org/10.1186/s12967-016-1051-1.

61. Fathi-Kazerooni M, Tavoosidana G. Menstrual blood stem cell transplantation in mice model of acute liver failure: does gender of recipient affect the outcome? Avicenna J Med Biotechnol. 2019;11:308.
62. Fathi-Kazerooni M, Tavoosidana G, Taghizadeh-Jahed M, Khanjani S, Golshahi H, Gargett CE, et al. Comparative restoration of acute liver failure by menstrual blood stem cells compared with bone marrow stem cells in mice model. Cytotherapy. 2017. https://doi.org/10.1016/j. jcyt.2017.08.022.

63. Borlongan CV, Kaneko Y, Maki M, Yu SJ, Ali M, Allickson JG, et al. Menstrual blood cells display stem cell-like phenotypic markers and exert neuroprotection following transplantation in experimental stroke. Stem Cells Dev. 2010. https://doi.org/10.1089/scd.2009.0340.

64. Chen X, Wu Y, Wang Y, Chen L, Zheng W, Zhou S, et al. Human menstrual blood-derived stem cells mitigate bleomycin-induced pulmonary fibrosis through anti-apoptosis and anti-inflammatory effects. Stem Cell Res Ther. 2020. https://doi.org/10.1186/s13287-020-01926-x.

65. Zhao Y, Lan X, Wang Y, Xu X, Lu S, Li X, et al. Human endometrial regenerative cells attenuate bleomycin-induced pulmonary fibrosis in mice. Stem Cells Int. 2018. https://doi.org/10.1155/2018/3475137.

66. Liu Y, Niu R, Li W, Lin J, Stamm C, Steinhoff G, et al. Therapeutic potential of menstrual blood-derived endometrial stem cells in cardiac diseases. Cell Mol Life Sci. 2019. https://doi.org/10.1007/s00018-019-03019-2.

67. Lan X, Wang G, Xu X, Lu S, Li X, Zhang B, et al. Stromal cell-derived factor-1 mediates cardiac allograft tolerance induced by human endometrial regenerative cell-based therapy. Stem Cells Transl Med. 2017. https://doi.org/10.1002/sctm.17-0091.

68. Zhang Z, Wang JA, Xu Y, Jiang Z, Wu R, Wang L, et al. Menstrual blood derived mesenchymal cells ameliorate cardiac fibrosis via inhibition of endothelial to mesenchymal transition in myocardial infarction. Int J Cardiol. 2013. https://doi.org/10.1016/j.ijcard.2013.03.126.

69. Zhao Y, Chen X, Wu Y, Wang Y, Li Y, Xiang C. Transplantation of human menstrual blood-derived mesenchymal stem cells alleviates Alzheimer's disease-like pathology in APP/PS1 transgenic mice. Front Mol Neurosci. 2018. https://doi.org/10.3389/fnmol.2018.00140.

70. Xiang B, Chen L, Wang X, Zhao Y, Wang Y, Xiang C. Transplantation of menstrual blood-derived mesenchymal stem cells promotes the repair of LPS-induced acute lung injury. Int J Mol Sci. 2017. https://doi.org/10. 3390/ijms18040689.

71. Chen J, Hu C, Chen L, Tang L, Zhu Y, Xu X, et al. Clinical study of mesenchymal stem cell treatment for acute respiratory distress syndrome induced by epidemic influenza A (H7N9) infection: a hint for COVID-19 treatment. Engineering (Beijing). 2020. https://doi.org/10.1016/j.eng. 2020.02.006.

72. Sun P, Liu J, Li W, Xu X, Gu X, Li H, et al. Human endometrial regenerative cells attenuate renal ischemia reperfusion injury in mice. J Transl Med. 2016. https://doi.org/10.1186/s12967-016-0782-3.

73. Farzamfar S, Naseri-Nosar M, Ghanavatinejad A, Vaez A, Zarnani AH, Salehi M. Sciatic nerve regeneration by transplantation of menstrual blood-derived stem cells. Mol Biol Rep. 2017. https://doi.org/10.1007/ s11033-017-4124-1.

74. Dalirfardouei $\mathrm{R}$, Jamialahmadi K, Jafarian AH, Mahdipour E. Promising effects of exosomes isolated from menstrual blood-derived mesenchymal stem cell on wound-healing process in diabetic mouse model. J Tissue Eng Regen Med. 2019. https://doi.org/10.1002/term.2799.

75. Wu X, Luo Y, Chen J, Pan R, Xiang B, Du X, et al. Transplantation of human menstrual blood progenitor cells improves hyperglycemia by promoting endogenous progenitor differentiation in type 1 diabetic mice. Stem Cells Dev. 2014. https://doi.org/10.1089/scd.2013.0390.

76. Zhu H, Pan Y, Jiang Y, Li J, Zhang Y, Zhang S. Activation of the Hippo/TAZ pathway is required for menstrual stem cells to suppress myofibroblast and inhibit transforming growth factor beta signaling in human endometrial stromal cells. Hum Reprod. 2019. https://doi.org/10.1093/ humrep/dez001.

77. Zhang S, Li P, Yuan Z, Tan J. Platelet-rich plasma improves therapeutic effects of menstrual blood-derived stromal cells in rat model of intrauterine adhesion. Stem Cell Res Ther. 2019. https://doi.org/10.1186/ s13287-019-1155-7.

78. Lai D, Wang F, Yao X, Zhang Q, Wu X, Xiang C. Human endometrial mesenchymal stem cells restore ovarian function through improving the renewal of germline stem cells in a mouse model of premature ovarian failure. J Transl Med. 2015. https://doi.org/10.1186/s12967-015-0516-y.

79. Kazemnejad S, Akhondi MM, Soleimani M, Zarnani AH, Khanmohammadi M, Darzi S, et al. Characterization and chondrogenic 
differentiation of menstrual blood-derived stem cells on a nanofibrous scaffold. Int J Artif Organs. 2012. https://doi.org/10.5301/ijao.5000019.

80. Fard M, Akhavan-Tavakoli M, Khanjani S, Zare S, Edalatkhah H, Arasteh $\mathrm{S}$, et al. Bilayer amniotic membrane/nano-fibrous fibroin scaffold promotes differentiation capability of menstrual blood stem cells into keratinocyte-like cells. Mol Biotechnol. 2018. https://doi.org/10.1007/ s12033-017-0049-0.

81. Rajabi Z, Yazdekhasti H, Noori Mugahi SMH, Abbasi M, Kazemnejad S, Shirazi A, et al. Mouse preantral follicle growth in 3D co-culture system using human menstrual blood mesenchymal stem cell. Reprod Biol. 2018. https://doi.org/10.1016/j.repbio.2018.02.001.

82. Phuc PV, Lam DH, Ngoc VB, Thu DT, Nguyet NT, Ngoc PK. Production of functional dendritic cells from menstrual blood: a new dendritic cell source for immune therapy. Vitro Cell Dev Biol Anim. 2011. https://doi. org/10.1007/s11626-011-9399-2.

83. Collin M, Bigley V. Human dendritic cell subsets: an update. Immunology. 2018. https://doi.org/10.1111/imm.12888.

84. Akbar SM, Furukawa S, Hasebe A, Horiike N, Michitaka K, Onji M. Production and efficacy of a dendritic cell-based therapeutic vaccine for murine chronic hepatitis B virus carrierer. Int J Mol Med. 2004;14:295-9.

85. Ding FX, Xian X, Guo YJ, Liu Y, Wang Y, Yang F, et al. A preliminary study on the activation and antigen presentation of hepatitis $B$ virus core protein virus-like particle-pulsed bone marrow-derived dendritic cells. Mol Biosyst. 2010. https://doi.org/10.1039/c005222a.

86. Bozorgmehr M, Moazzeni SM, Salehnia M, Sheikhian A, Nikoo S, Zarnani AH. Menstrual blood-derived stromal stem cells inhibit optimal generation and maturation of human monocyte-derived dendritic cells. Immunol Lett. 2014. https://doi.org/10.1016/j.imlet.2014.10.005.

87. Nikoo S, Ebtekar M, Jeddi-Tehrani M, Shervin A, Bozorgmehr M, Kazemnejad S, et al. Effect of menstrual blood-derived stromal stem cells on proliferative capacity of peripheral blood mononuclear cells in allogeneic mixed lymphocyte reaction. J Obstet Gynaecol Res. 2012. https://doi.org/10.1111/j.1447-0756.2011.01800.x.

88. Luz-Crawford P, Torres MJ, Noël D, Fernandez A, Toupet K, AlcayagaMiranda F, et al. The immunosuppressive signature of menstrual blood mesenchymal stem cells entails opposite effects on experimental arthritis and graft versus host diseases. Stem Cells. 2016. https://doi.org/ 10.1002/stem.2244.

89. Xu X, Wang Y, Zhang B, Lan X, Lu S, Sun P, et al. Treatment of experimental colitis by endometrial regenerative cells through regulation of $B$ lymphocytes in mice. Stem Cell Res Ther. 2018. https://doi.org/10.1186/ s13287-018-0874-5.

90. Xu X, Li X, Gu X, Zhang B, Tian W, Han H, et al. Prolongation of cardiac allograft survival by endometrial regenerative cells: focusing on B-cell responses. Stem Cells Transl Med. 2017. https://doi.org/10.5966/sctm. 2016-0206.

91. Zhou S, Schuetz JD, Bunting KD, Colapietro AM, Sampath J, Morris JJ, et al. The $A B C$ transporter Bcrp1/ABCG2 is expressed in a wide variety of stem cells and is a molecular determinant of the side-population phenotype. Nat Med. 2001. https://doi.org/10.1038/nm0901-1028.

92. Kato K, Yoshimoto M, Kato K, Adachi S, Yamayoshi A, Arima T, et al. Characterization of side-population cells in human normal endometrium. Hum Reprod. 2007. https://doi.org/10.1093/humrep/del514.

93. Masuda H, Matsuzaki Y, Hiratsu E, Ono M, Nagashima T, Kajitani T, et al. Stem cell-like properties of the endometrial side population: implication in endometrial regeneration. PLoS ONE. 2010. https://doi.org/10. 1371/journal.pone.0010387.

94. Tsuji S, Yoshimoto M, Takahashi K, Noda Y, Nakahata T, Heike T. Side population cells contribute to the genesis of human endometrium. Fertil Steril. 2008. https://doi.org/10.1016/j.fertnstert.2007.08.005.

95. Qu WW, Huang W, Wang CX, Li SF, Liu YF, Guo C. Identification and clonogenicity of side-population cells in human decidua of first trimester pregnancy. Zhonghua Yi Xue Za Zhi. 2008;88:2369-71.

96. Cervelló I, Gil-Sanchis C, Mas A, Delgado-Rosas F, Martínez-Conejero JA, Galán A, et al. Human endometrial side population cells exhibit genotypic, phenotypic and functional features of somatic stem cells. PLoS ONE. 2010. https://doi.org/10.1371/journal.pone.0010964.

97. Cervelló I, Mas A, Gil-Sanchis C, Peris L, Faus A, Saunders PT, et al. Reconstruction of endometrium from human endometrial side population cell lines. PLoS ONE. 2011. https://doi.org/10.1371/journal.pone.00212 21.

98. Gurung S, Deane JA, Masuda H, Maruyama T, Gargett CE. Stem cells in endometrial physiology. Semin Reprod Med. 2015. https://doi.org/10. 1055/s-0035-1558405.

99. Guo C, Zhu H, Huang W, Li S, Qu W, Liu Y, et al. Side population cells in the human decidua of early pregnancy exhibit stem/progenitor cell-like characteristics. Reprod Biomed Online. 2010. https://doi.org/10.1016/j. rbmo.2010.07.010.

100. Miyazaki K, Maruyama T, Masuda H, Yamasaki A, Uchida S, Oda H, et al. Stem cell-like differentiation potentials of endometrial side population cells as revealed by a newly developed in vivo endometrial stem cell assay. PLoS ONE. 2012. https://doi.org/10.1371/journal.pone.0050749.

101. Cervello I, Mas A, Gil-Sanchis C, Peris L, Faus A, Saunders PT, et al. Reconstruction of endometrium from human endometrial side population cell lines. PLoS ONE. 2011. https://doi.org/10.1371/journal.pone.00212 21.

102. Maruyama T. Stem/progenitor cells and the regeneration potentials in the human uterus. Reprod Med Biol. 2010. https://doi.org/10.1007/ s12522-009-0032-y.

103. Masuda H, Maruyama T, Gargett CE, Miyazaki K, Matsuzaki Y, Okano H, et al. Endometrial side population cells: potential adult stem/progenitor cells in endometrium. Biol Reprod. 2015. https://doi.org/10.1095/biolr eprod. 115.131490.

104. Valentijn AJ, Palial K, Al-Lamee H, Tempest N, Drury J, Von Zglinicki T, et al. SSEA-1 isolates human endometrial basal glandular epithelial cells: phenotypic and functional characterization and implications in the pathogenesis of endometriosis. Hum Reprod. 2013. https://doi.org/10. 1093/humrep/det285.

105. Nguyen HP, Sprung CN, Gargett CE. Differential expression of Wnt signaling molecules between pre- and postmenopausal endometrial epithelial cells suggests a population of putative epithelial stem/progenitor cells reside in the basalis layer. Endocrinology. 2012. https://doi. org/10.1210/en.2011-1839.

106. Tempest N, Jansen M, Baker AM, Hill CJ, Hale M, Magee D, et al. Histological 3D reconstruction and in vivo lineage tracing of the human endometrium. J Pathol. 2020. https://doi.org/10.1002/path.5478.

107. Syed SM, Kumar M, Ghosh A, Tomasetig F, Ali A, Whan RM, et al. Endometrial Axin2(+) cells drive epithelial homeostasis, regeneration, and cancer following oncogenic transformation. Cell Stem Cell. 2020. https://doi.org/10.1016/j.stem.2019.11.012.

108. Nusse R, Clevers H. Wnt/ $\beta$-catenin signaling, disease, and emerging therapeutic modalities. Cell. 2017. https://doi.org/10.1016/j.cell.2017.05. 016.

109. Cousins FL, Pandoy R, Jin S, Gargett CE. The elusive endometrial epithelial stem/progenitor cells. Front Cell Dev Biol. 2021. https://doi.org/10. 3389/fcell.2021.640319.

110. Ghosh A, Syed SM, Kumar M, Carpenter TJ, Teixeira JM, Houairia N, et al. In vivo cell fate tracing provides no evidence for mesenchymal to epithelial transition in adult fallopian tube and uterus. Cell Rep. 2020. https://doi.org/10.1016/j.celrep.2020.107631.

111. Jin S. Bipotent stem cells support the cyclical regeneration of endometrial epithelium of the murine uterus. Proc Natl Acad Sci U S A. 2019. https://doi.org/10.1073/pnas.1814597116.

112. Singh P, Bhartiya D. Pluripotent stem (VSELs) and progenitor (EnSCs) cells exist in adult mouse uterus and show cyclic changes across estrus cycle. Reprod Sci. 2021. https://doi.org/10.1007/s43032-020-00250-2.

113. Ivanovic Z. Human umbilical cord blood-derived very-small-embryoniclike stem cells with maximum regenerative potential? Stem Cells Dev. 2012. https://doi.org/10.1089/scd.2012.0058.

114. Starzinski-Powitz A, Zeitvogel A, Schreiner A, Baumann R. Endometriosis: a stem cell disease? Zentralbl Gynakol. 2003. https://doi.org/10. 1055/s-2003-42276.

115. LiT, He H, Liu R, Wang SX, Pu DM. Isolation and identification of epithelial and stromal stem cells from eutopic endometrium of women with endometriosis. Eur J Obstet Gynecol Reprod Biol. 2014. https://doi.org/ 10.1016/j.ejogrb.2014.04.001.

116. Götte M, Wolf M, Staebler A, Buchweitz O, Kelsch R, Schüring AN, et al. Increased expression of the adult stem cell marker Musashi-1 in 
endometriosis and endometrial carcinoma. J Pathol. 2008. https://doi. org/10.1002/path.2364.

117. Proestling K, Birner P, Balendran S, Nirtl N, Marton E, Yerlikaya G, et al. Enhanced expression of the stemness-related factors OCT4, SOX15 and TWIST1 in ectopic endometrium of endometriosis patients. Reprod Biol Endocrinol. 2016. https://doi.org/10.1186/s12958-016-0215-4.

118. Götte M, Wolf M, Staebler A, Buchweitz O, Kiesel L, Schüring AN. Aberrant expression of the pluripotency marker SOX-2 in endometriosis. Fertil Steril. 2011. https://doi.org/10.1016/j.fertnstert.2010.08.006.

119. Uzan C, Cortez A, Dufournet C, Fauvet R, Siffroi JP, Daraï E. Endometrium from women with and without endometriosis, and peritoneal, ovarian and bowel endometriosis, show different c-kit protein expression. J Reprod Immunol. 2005. https://doi.org/10.1016/j.jri.2004.09.002.

120. Talora C, Campese AF, Bellavia D, Felli MP, Vacca A, Gulino A, et al. Notch signaling and diseases: an evolutionary journey from a simple beginning to complex outcomes. Biochim Biophys Acta. 2008. https://doi. org/10.1016/j.bbadis.2008.06.008.

121. Zeng B, Hu J, Yuan R, Hu L, Zhong L, Kang K. Increased expression of importin 13 in endometriosis and endometrial carcinoma. Med Sci Monit. 2012. https://doi.org/10.12659/msm.882879.

122. Dracxler RC, Oh C, Kalmbach K, Wang F, Liu L, Kallas EG, et al. Peripheral blood telomere content is greater in patients with endometriosis than in controls. Reprod Sci. 2014. https://doi.org/10.1177/1933719114 527353.

123. Othman ER, Meligy FY, Sayed AA, El-Mokhtar MA, Refaiy AM. Stem cell markers describe a transition from somatic to pluripotent cell states in a rat model of endometriosis. Reprod Sci. 2018. https://doi.org/10.1177/ 1933719117697124

124. Perricos A, Wenzl R, Husslein H, Eiwegger T, Gstoettner M, Weinhaeusel $A$, et al. Does the use of the "Proseek $\left({ }^{\circledR}\right)$ multiplex oncology I panel" on peritoneal fluid allow a better insight in the pathophysiology of endometriosis, and in particular deep-infiltrating endometriosis? J Clin Med. 2020. https://doi.org/10.3390/jcm9062009.

125. Hou Z, Sun L, Gao L, Liao L, Mao Y, Liu J. Cytokine array analysis of peritoneal fluid between women with endometriosis of different stages and those without endometriosis. Biomarkers. 2009. https://doi.org/10. 3109/13547500903183970.

126. Lebovic DI, Chao VA, Martini JF, Taylor RN. IL-1 beta induction of RANTES (regulated upon activation, normal T cell expressed and secreted) chemokine gene expression in endometriotic stromal cells depends on a nuclear factor-kappaB site in the proximal promoter. J Clin Endocrinol Metab. 2001. https://doi.org/10.1210/jcem.86.10.7890.

127. Hornung D, Klingel K, Dohrn K, Kandolf R, Wallwiener D, Taylor RN. Regulated on activation, normal T-cell-expressed and -secreted mRNA expression in normal endometrium and endometriotic implants: assessment of autocrine/paracrine regulation by in situ hybridization. Am J Pathol. 2001. https://doi.org/10.1016/s0002-9440(10)64664-0.

128. Halme J, Becker S, Hammond MG, Raj MH, Raj S. Increased activation of pelvic macrophages in infertile women with mild endometriosis. Am J Obstet Gynecol. 1983. https://doi.org/10.1016/0002-9378(83)90720-2.

129. Zheng J, Qu J, Lu P, Hou Z, Cui Y, Mao Y, et al. Activin A stimulates aromatase via the ALK4-smad pathway in endometriosis. Biomed Res Int. 2016. https://doi.org/10.1155/2016/5791510

130. Rombauts L, Donoghue J, Cann L, Jones RL, Healy DL. Activin-A secretion is increased in the eutopic endometrium from women with endometriosis. Aust N Z J Obstet Gynaecol. 2006. https://doi.org/10. 1111/j.1479-828X.2006.00546.x.

131. Luckow Invitti A, Schor E, Martins Parreira R, Kopelman A, Kamergorodsky G, Gonçalves GA, et al. Inflammatory cytokine profile of co-cultivated primary cells from the endometrium of women with and without endometriosis. Mol Med Rep. 2018. https://doi.org/10.3892/mmr.2018. 9137.

132. Kasai K, Kato T, Kadota Y, Erdenebayar O, Keyama K, Kawakita T, et al. Intraperitoneal administration of activin A promotes development of endometriotic lesions in a mouse model of endometriosis. J Med Invest. 2019. https://doi.org/10.2152/jmi.66.123.

133. Moggio A, Pittatore G, Cassoni P, Marchino GL, Revelli A, Bussolati B. Sorafenib inhibits growth, migration, and angiogenic potential of ectopic endometrial mesenchymal stem cells derived from patients with endometriosis. Fertil Steril. 2012. https://doi.org/10.1016/j.fertn stert.2012.08.003.
134. Chen YJ, Li HY, Chang YL, Yuan CC, Tai LK, Lu KH, et al. Suppression of migratory/invasive ability and induction of apoptosis in adenomyosisderived mesenchymal stem cells by cyclooxygenase- 2 inhibitors. Fertil Steril. 2010. https://doi.org/10.1016/j.fertnstert.2010.01.070.

135. Ponandai-Srinivasan S, Andersson KL, Nister M, Saare M, Hassan HA, Varghese SJ, et al. Aberrant expression of genes associated with stemness and cancer in endometria and endometrioma in a subset of women with endometriosis. Hum Reprod. 2018. https://doi.org/10.1093/humrep/dey241.

136. Nikoo S, Ebtekar M, Jeddi-Tehrani M, Shervin A, Bozorgmehr M, Vafaei $S$, et al. Menstrual blood-derived stromal stem cells from women with and without endometriosis reveal different phenotypic and functional characteristics. Mol Hum Reprod. 2014. https://doi.org/10.1093/molehr/ gau044.

137. Du H, Taylor HS. Contribution of bone marrow-derived stem cells to endometrium and endometriosis. Stem Cells. 2007. https://doi.org/10. 1634/stemcells.2006-0828.

138. Chen P, Mamillapalli R, Habata S, Taylor HS. Endometriosis cell proliferation induced by bone marrow mesenchymal stem cells. Reprod Sci. 2021. https://doi.org/10.1007/s43032-020-00294-4.

139. Sakr S, Naqvi H, Komm B, Taylor HS. Endometriosis impairs bone marrow-derived stem cell recruitment to the uterus whereas bazedoxifene treatment leads to endometriosis regression and improved uterine stem cell engraftment. Endocrinology. 2014. https://doi.org/10.1210/ en.2013-1977.

140. Chen P, Mamillapalli R, Habata S, Taylor HS. Endometriosis stromal cells induce bone marrow mesenchymal stem cell differentiation and PD-1 expression through paracrine signaling. Mol Cell Biochem. 2021. https://doi.org/10.1007/s11010-020-04012-1.

141. Pluchino N, Taylor HS. Endometriosis and stem cell trafficking. Reprod Sci. 2016. https://doi.org/10.1177/1933719116671219.

142. Zhang W, Li X, Li H, Lu X, Chen J, Li L, et al. 17ß-estradiol promotes bone marrow mesenchymal stem cell migration mediated by chemokine upregulation. Biochem Biophys Res Commun. 2020. https://doi.org/10. 1016/j.bbrc.2020.07.135.

143. Ersoy GS, Zolbin MM, Cosar E, Mamillapalli R, Taylor HS. Medical therapies for endometriosis differentially inhibit stem cell recruitment. Reprod Sci. 2017. https://doi.org/10.1177/1933719116682879.

144. Wang X, Mamillapalli R, Mutlu L, Du H, Taylor HS. Chemoattraction of bone marrow-derived stem cells towards human endometrial stromal cells is mediated by estradiol regulated CXCL12 and CXCR4 expression. Stem Cell Res. 2015. https://doi.org/10.1016/j.scr.2015.04.004.

145. Moridi I, Mamillapalli R, Cosar E, Ersoy GS, Taylor HS. Bone marrow stem cell chemotactic activity is induced by elevated CXCl12 in endometriosis. Reprod Sci. 2017. https://doi.org/10.1177/1933719116672587.

146. Hufnagel D, Li F, Cosar E, Krikun G, Taylor HS. The Role of Stem cells in the etiology and pathophysiology of endometriosis. Semin Reprod Med. 2015. https://doi.org/10.1055/s-0035-1564609.

147. Pluchino N, Mamillapalli R, Shaikh S, Habata S, Tal A, Gaye M, et al. CXCR4 or CXCR7 antagonists treat endometriosis by reducing bone marrow cell trafficking. J Cell Mol Med. 2020. https://doi.org/10.1111/ jcmm.14933.

148. Pospisilova E, Kiss I, Souckova H, Tomes P, Spicka J, Matkowski R, et al. Circulating endometrial cells: a new source of information on endometriosis dynamics. J Clin Med. 2019. https://doi.org/10.3390/jcm8111938.

149. Kiss I, Pospisilova E, Kolostova K, Maly V, Stanek I, Lischke R, et al. Circulating endometrial cells in women with spontaneous pneumothorax. Chest. 2020. https://doi.org/10.1016/j.chest.2019.09.008.

150. Nguyen HPT, Xiao L, Deane JA, Tan KS, Cousins FL, Masuda H, et al. $\mathrm{N}$-cadherin identifies human endometrial epithelial progenitor cells by in vitro stem cell assays. Hum Reprod. 2017. https://doi.org/10.1093/ humrep/dex289.

151. Domnina A, Novikova P, Obidina J, Fridlyanskaya I, Alekseenko L, Kozhukharova I, et al. Human mesenchymal stem cells in spheroids improve fertility in model animals with damaged endometrium. Stem Cell Res Ther. 2018. https://doi.org/10.1186/s13287-018-0801-9.

152. Zhang $Y$, Lin $X$, Dai Y, Hu X, Zhu H, Jiang Y, et al. Endometrial stem cells repair injured endometrium and induce angiogenesis via AKT and ERK pathways. Reproduction. 2016. https://doi.org/10.1530/rep-16-0286. 
153. Cen PP, Fan LX, Wang J, Chen JJ, Li LJ. Therapeutic potential of menstrual blood stem cells in treating acute liver failure. World J Gastroenterol. 2019. https://doi.org/10.3748/wjg.v25.i41.6190.

154. Chen L, Zhang C, Chen L, Wang X, Xiang B, Wu X, et al. Human menstrual blood-derived stem cells ameliorate liver fibrosis in mice by targeting hepatic stellate cells via paracrine mediators. Stem Cells Transl Med. 2017. https://doi.org/10.5966/sctm.2015-0265.

\section{Publisher's Note}

Springer Nature remains neutral with regard to jurisdictional claims in published maps and institutional affiliations.
Ready to submit your research? Choose BMC and benefit from:

- fast, convenient online submission

- thorough peer review by experienced researchers in your field

- rapid publication on acceptance

- support for research data, including large and complex data types

- gold Open Access which fosters wider collaboration and increased citations

- maximum visibility for your research: over 100M website views per year

At BMC, research is always in progress.

Learn more biomedcentral.com/submissions 